Universidad

:

BIBLIOTECA

Document downloaded from the institutional repository of the University of Alcala: https://ebuah.uah.es/dspace/

This is a postprint version of the following published document:

Carbó, J.J. et al., 2009. Lewis Base Behavior of Bridging Nitrido Ligands of Titanium Polynuclear Complexes. Chemistry - A European Journal, 15(43), pp.11619-11631.

Available at https://doi.org/10.1002/chem.200901598

(C) 2009 Wiley-VCH Verlag.
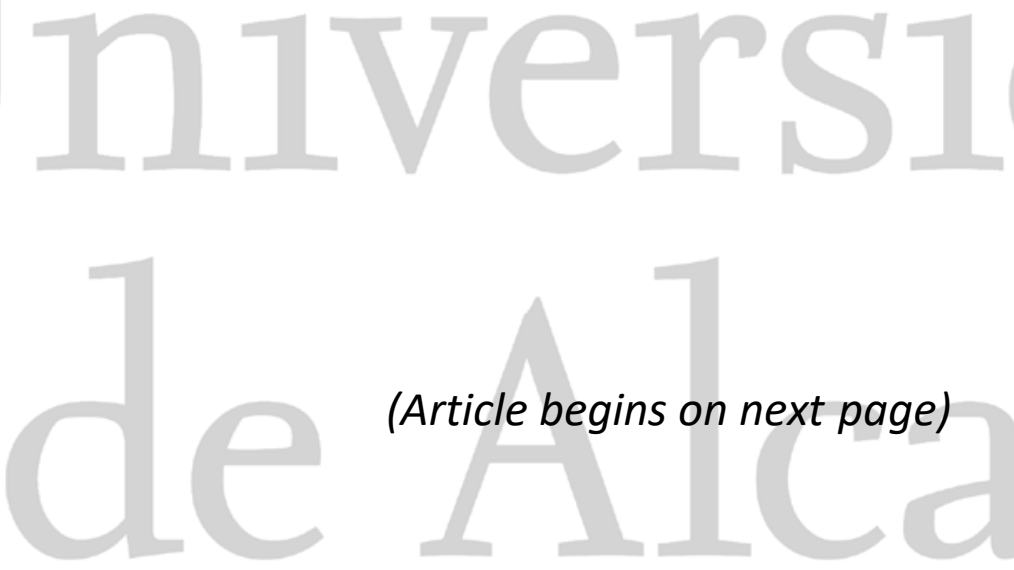

(Article begins on next page)

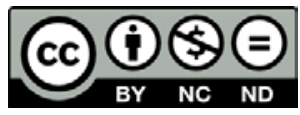

This work is licensed under a

Creative Commons Attribution-NonCommercial-NoDerivatives

4.0 International License. 


\section{Lewis Base Behavior of Bridging Nitrido Ligands of Titanium Polynuclear Complexes}

Jorge J. Carbó,${ }^{[\mathrm{b}] *}$ Noelia Martínez-Espada, ${ }^{[\mathrm{a}]}$ Miguel Mena, ${ }^{[\mathrm{a}]}$ Marta E. G. Mosquera, ${ }^{[\mathrm{a}]}$ JosepM. Poblet, ${ }^{[\mathrm{b}]}$ and Carlos Yélamos ${ }^{[\mathrm{a}] *}$

Dedicated to our collaborator Dr. J. P. Sarasa, deceased on August 2008.

[a] N. Martínez-Espada, Dr. M. Mena, Dr. M. E. G. Mosquera, Dr. C. Yélamos

Departamento de Química Inorgánica, Universidad de Alcalá

28871 Alcalá de Henares-Madrid (Spain)

FAX: (+34) 91-8854683

E-mail: carlos.yelamos@uah.es

[b] Dr. J. J. Carbó, Prof. J.-M. Poblet

Department de Química Física i Inorgánica, Universitat Rovira i Virgili

Marcel-lí Domingo s/n, 43007 Tarragona (Spain)

FAX: (+34) 977-559563

E-mail: j.carbo@urv.cat

Supporting information for this article is available on the WWW under http://dx.doi.org/10.1002/chem.200901598. 


\section{Text for the Table of Contents}

\section{Eye-Catching Headline: Cage Compounds}

Text: One, two or up to three MX Lewis acids can be incorporated at the $\mu_{3}$-nitrido ligands of the tetranuclear nitrido cube $\left[\left\{\mathrm{Ti}\left(\eta^{5}-\mathrm{C}_{5} \mathrm{Me}_{5}\right)\right\}_{4}\left(\mu_{3}-\mathrm{N}\right)_{4}\right]$ (see picture). The $\mu_{3}-\mathrm{N}$ apical group of the imido-nitrido trinuclear complex $\left[\left\{\mathrm{Ti}\left(\eta^{5}-\mathrm{C}_{5} \mathrm{Me}_{5}\right)(\mu-\mathrm{NH})\right\}_{3}\left(\mu_{3}-\mathrm{N}\right)\right]$ is also capable of acting as a Lewis base to $\mathrm{MX}$ although coordination through the three basal $\mathrm{NH}$ imido ligands is thermodynamically preferred.

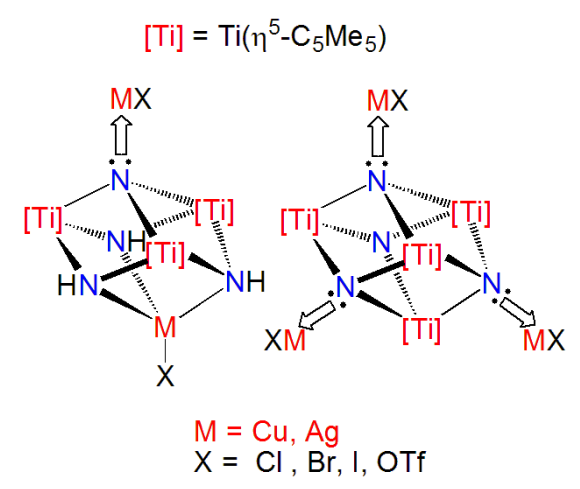

Keywords: cage compounds $\cdots$ cubanes $\cdots$ density functional calculations $\cdots$ nitrides $\cdots$ titanium 


\section{Abstract:}

The Lewis base behavior of $\mu_{3}$-nitrido ligands of the polynuclear titanium complexes $\left[\left\{\operatorname{Ti}\left(\eta^{5}-\right.\right.\right.$ $\left.\left.\left.\mathrm{C}_{5} \mathrm{Me}_{5}\right)(\mu-\mathrm{NH})\right\}_{3}\left(\mu_{3}-\mathrm{N}\right)\right](\mathbf{1})$ and $\left[\left\{\mathrm{Ti}\left(\eta^{5}-\mathrm{C}_{5} \mathrm{Me}_{5}\right)\right\}_{4}\left(\mu_{3}-\mathrm{N}\right)_{4}\right](2)$ to MX Lewis acids has been observed for the first time. Complex 1 entraps one equivalent of copper(I) halide or copper(I) trifluoromethanesulfonate through the basal $\mathrm{NH}$ imido groups to give cube-type adducts $\left[\mathrm{XCu}\left\{\left(\mu_{3}-\mathrm{NH}\right)_{3} \mathrm{Ti}_{3}\left(\eta^{5}-\mathrm{C}_{5} \mathrm{Me}_{5}\right)_{3}\left(\mu_{3}-\mathrm{N}\right)\right\}\right]\left(\mathrm{X}=\mathrm{Cl}(\mathbf{3}), \mathrm{Br}(\mathbf{4}), \mathrm{I}(\mathbf{5}), \mathrm{OSO}_{2} \mathrm{CF}_{3}(\mathbf{6})\right)$. However, the treatment of 1 with excess ( $\geq 2$ equiv) of copper reagents afforded complexes $\left[\mathrm{XCu}\left\{\left(\mu_{3^{-}}\right.\right.\right.$ $\left.\left.\mathrm{NH})_{3} \mathrm{Ti}_{3}\left(\eta^{5}-\mathrm{C}_{5} \mathrm{Me}_{5}\right)_{3}\left(\mu_{4}-\mathrm{N}\right)(\mathrm{CuX})\right\}\right]\left(\mathrm{X}=\mathrm{Cl}(\mathbf{7}), \mathrm{Br}(\mathbf{8}), \mathrm{I}(\mathbf{9}), \mathrm{OSO}_{2} \mathrm{CF}_{3}(\mathbf{1 0})\right)$ by incorporation of an additional $[\mathrm{CuX}]$ fragment at the $\mu_{3}-\mathrm{N}$ nitrido apical group. Similarly, the tetranuclear cube-type nitrido derivative $\mathbf{2}$ is capable of incorporating one, two or up to three [CuX] units at the $\mu_{3}-\mathrm{N}$ ligands to give complexes $\left[\left\{\mathrm{Ti}\left(\eta^{5}-\mathrm{C}_{5} \mathrm{Me}_{5}\right)\right\}_{4}\left(\mu_{3}-\mathrm{N}\right)_{4-\mathrm{n}}\left\{\left(\mu_{4}-\mathrm{N}\right) \mathrm{CuX}\right\}_{\mathrm{n}}\right](\mathrm{X}=\mathrm{Br}(\mathbf{1 1})$, $\left.\mathrm{n}=1 ; \mathrm{X}=\mathrm{Cl}(\mathbf{1 2}), \mathrm{n}=2 ; \mathrm{X}=\mathrm{OSO}_{2} \mathrm{CF}_{3}(\mathbf{1 3}), \mathrm{n}=3\right)$. Compound 2 also reacts with silver(I) trifluoromethanesulfonate $\left(\geq 1\right.$ equiv) to give the adduct $\left[\left\{\mathrm{Ti}\left(\eta^{5}-\mathrm{C}_{5} \mathrm{Me}_{5}\right)\right\}_{4}\left(\mu_{3}-\mathrm{N}\right)_{3}\left\{\left(\mu_{4}-\right.\right.\right.$ N) $\left.\mathrm{AgOSO}_{2} \mathrm{CF}_{3}\right\}$ ] (14). X-ray crystal structure determinations have been performed for complexes 8-13. Density functional theory calculations have been carried out to understand the nature and strength of the interactions of $\left[\left\{\mathrm{Ti}\left(\eta^{5}-\mathrm{C}_{5} \mathrm{H}_{5}\right)(\mu-\mathrm{NH})\right\}_{3}\left(\mu_{3}-\mathrm{N}\right)\right]\left(\mathbf{1}^{\prime}\right)$ and $\left[\left\{\mathrm{Ti}\left(\eta^{5}-\right.\right.\right.$ $\left.\left.\left.\mathrm{C}_{5} \mathrm{H}_{5}\right)\right\}_{4}\left(\mu_{3}-\mathrm{N}\right)_{4}\right]$ (2') model complexes with copper and silver [MX] fragments. Although in the case of 1' coordination through the three basal NH imido groups is thermodynamically preferred, in both complexes the $\mu_{3}$-nitrido groups act as two-electron donor Lewis bases to the appropriate Lewis acids. 


\section{Abstract in Spanish:}

Los ligandos $\mu_{3}$-nitruro de los complejos polinucleares de titanio $\left[\left\{\mathrm{Ti}\left(\eta^{5}-\mathrm{C}_{5} \mathrm{Me}_{5}\right)(\mu-\mathrm{NH})\right\}_{3}\left(\mu_{3^{-}}\right.\right.$ $\mathrm{N})](\mathbf{1})$ y $\left[\left\{\mathrm{Ti}\left(\eta^{5}-\mathrm{C}_{5} \mathrm{Me}_{5}\right)\right\}_{4}\left(\mu_{3}-\mathrm{N}\right)_{4}\right](\mathbf{2})$ pueden tener un comportamiento como bases cuando se enfrentan a ácidos de Lewis MX. El complejo 1 incorpora un equivalente de haluro de cobre(I) o trifluorometanosulfonato de cobre(I) a través de los grupos imido $\mathrm{NH}$ basales para dar los aductos tipo-cubo $\left[\mathrm{XCu}\left\{\left(\mu_{3}-\mathrm{NH}\right)_{3} \mathrm{Ti}_{3}\left(\eta^{5}-\mathrm{C}_{5} \mathrm{Me}_{5}\right)_{3}\left(\mu_{3}-\mathrm{N}\right)\right\}\right]\left(\mathrm{X}=\mathrm{Cl}(\mathbf{3}), \mathrm{Br}(\mathbf{4}), \mathrm{I}(\mathbf{5}), \mathrm{OSO}_{2} \mathrm{CF}_{3}\right.$ (6)). Sin embargo, el tratamiento del compuesto 1 con exceso ( $\geq 2$ equivalentes) de los reactivos de cobre conduce a los complejos $\left[\mathrm{XCu}\left\{\left(\mu_{3}-\mathrm{NH}\right)_{3} \mathrm{Ti}_{3}\left(\eta^{5}-\mathrm{C}_{5} \mathrm{Me}_{5}\right)_{3}\left(\mu_{4}-\mathrm{N}\right)(\mathrm{CuX})\right\}\right](\mathrm{X}=\mathrm{Cl}(7), \mathrm{Br}$ (8), I (9), $\left.\mathrm{OSO}_{2} \mathrm{CF}_{3}(\mathbf{1 0})\right)$ mediante la incorporación de un fragmento adicional [CuX] al grupo nitruro apical $\left(\mu_{3}-\mathrm{N}\right)$. De forma similar, el derivado tetranuclear tipo-cubo 2 es capaz de incorporar uno, dos o hasta tres unidades $[\mathrm{CuX}]$ para dar los complejos $\left[\left\{\mathrm{Ti}\left(\eta^{5}-\mathrm{C}_{5} \mathrm{Me}_{5}\right)\right\}_{4}\left(\mu_{3^{-}}\right.\right.$ $\left.\mathrm{N})_{4-\mathrm{n}}\left\{\left(\mu_{4}-\mathrm{N}\right) \mathrm{CuX}\right\}_{\mathrm{n}}\right]\left(\mathrm{X}=\mathrm{Br}(\mathbf{1 1}), \mathrm{n}=1 ; \mathrm{X}=\mathrm{Cl}(\mathbf{1 2}), \mathrm{n}=2 ; \mathrm{X}=\mathrm{OSO}_{2} \mathrm{CF}_{3}(\mathbf{1 3}), \mathrm{n}=3\right) . \mathrm{El}$ compuesto 2 también reacciona con trifluorometanosulfonato de plata(I) ( $\geq 1$ equivalente) y origina el aducto $\left[\left\{\mathrm{Ti}\left(\eta^{5}-\mathrm{C}_{5} \mathrm{Me}_{5}\right)\right\}_{4}\left(\mu_{3}-\mathrm{N}\right)_{3}\left\{\left(\mu_{4}-\mathrm{N}\right) \mathrm{AgOSO}_{2} \mathrm{CF}_{3}\right\}\right]$ (14). Las estructuras cristalinas de los complejos 8-13 se han determinado mediante difracción de rayos-X de monocristal. Cálculos basados en la Teoría del Funcional de la Densidad permiten describir las interacciones de los complejos modelo $\left[\left\{\mathrm{Ti}\left(\eta^{5}-\mathrm{C}_{5} \mathrm{H}_{5}\right)(\mu-\mathrm{NH})\right\}_{3}\left(\mu_{3}-\mathrm{N}\right)\right]\left(\mathbf{1}^{\prime}\right)$ y $\left[\left\{\operatorname{Ti}\left(\eta^{5}-\mathrm{C}_{5} \mathrm{H}_{5}\right)\right\}_{4}\left(\mu_{3}-\mathrm{N}\right)_{4}\right]\left(\mathbf{2}^{\prime}\right)$ con fragmentos MX de cobre y plata. En ambos casos los grupos $\mu_{3}$-nitruro pueden actuar como bases de Lewis, aunque el complejo 1' prefiere coordinarse a través de las unidades imido $\mathrm{NH}$. 


\section{Introduction}

The chemistry of transition-metal nitrido complexes has attracted much attention in the past few decades. ${ }^{[1,2]}$ Nitrido complexes of group 6-8 metals usually bear the nitrido ligands as a terminal functionality $[\mathrm{M}] \equiv \mathrm{N}$, and their bonding and reactivity have been extensively studied. ${ }^{\left[{ }_{1}, 3\right]}$ Terminal nitrido ligands of these mid-transition-metal compounds may display nucleophilic or electrophilic behavior (Scheme 1, Eq. A and B, respectively) depending of the nature of the metal, its oxidation state and the ancillary ligands. Thus, nitrido complexes $\left(\mathrm{L}_{\mathrm{n}} \mathrm{M} \equiv \mathrm{N}\right)$ react with electrophiles, such as methyltriflate, trifluoroacetic anhydride, and trityl tetrafluoroborate to produce imido derivatives $\left(\mathrm{L}_{n} \mathrm{M}=\mathrm{NR}\right)$ with no change in the oxidation state of the metal. ${ }^{[4]}$ In contrast, the reactions with nucleophiles, such as organic phosphanes, carbanions, and alkenes result in a two-electron reduction of the metal center and a reduced bond between the metal and nitrogen atom. ${ }^{[5]}$

$$
\begin{array}{ll}
{[\mathrm{M} \equiv \mathrm{N}:]+\mathrm{Elec} \longrightarrow[\mathrm{M}(=\mathrm{N}-\text { Elec })]} & (\mathbf{A}) \\
{\left[\mathrm{M}^{n+} \equiv \mathrm{N}:\right]+\mathrm{Nuc} \longrightarrow\left[\mathrm{M}^{(n-2)+}(\mathrm{NNuc})\right]} & (\mathbf{B}) \\
{[\mathrm{M} \equiv \mathrm{N}:]+\mathrm{Ac} \rightleftharpoons[\mathrm{M} \equiv \mathrm{N} \rightarrow \mathrm{Ac}]} & \text { (C) }
\end{array}
$$

Scheme 1. Simplified representations of the reactivity of the terminal nitrido moiety.

Under certain circumstances, the terminal nitrido moiety also behaves as a Lewis base to the appropriate Lewis acid (Scheme 1, Eq. C). Thus, the nitrido ligand coordinates reversibly to the Lewis acids to form adducts containing a nitrido bridge. Traditional Lewis acids employed in this reaction include group 13 compounds, such as $\mathrm{EX}_{3}(\mathrm{E}=\mathrm{B}, \mathrm{Al}, \mathrm{Ga}$, In; $\left.\mathrm{X}=\mathrm{F}, \mathrm{Cl}, \mathrm{Br}, \mathrm{I}, \mathrm{Ph}, \mathrm{C}_{6} \mathrm{~F}_{5}\right),{ }^{[6,7]}$ and group 14 chlorides $\mathrm{ECl}_{2}(\mathrm{E}=\mathrm{Ge}, \mathrm{Sn}) .{ }^{\left[{ }_{7}\right]}$ More recently, Strähle and co-workers have intensively studied the reactivity of mononuclear rhenium and osmium nitrido complexes with transition metal halides to form heterometallic complexes 
with $\mathrm{Re} \equiv \mathrm{N} \rightarrow \mathrm{M}$ or $\mathrm{Os} \equiv \mathrm{N} \rightarrow \mathrm{M}$ nitrido bridges $(\mathrm{M}=\mathrm{Ti}, \mathrm{Zr}, \mathrm{V}, \mathrm{Nb}, \mathrm{Ta}, \mathrm{Mo}, \mathrm{Rh}, \mathrm{Ir}, \mathrm{Ni}, \mathrm{Pd}, \mathrm{Pt}$, $\mathrm{Au}, \mathrm{Zn}) \cdot{ }^{[8]}$

Titanium complexes (or group 4 complexes) bearing terminal nitrido ligands are unknown and, only recently, two complexes containing an unprecedented terminal $\mathrm{Ti} \equiv \mathrm{N}$ moiety stabilized by coordination to $\mathrm{B}\left(\mathrm{C}_{6} \mathrm{~F}_{5}\right)_{3}$ have been structurally characterized. ${ }^{[9]}$ Thus, nitrido complexes of the early transition metals (groups 4 and 5) usually form singular polynuclear structures with $\mu_{\mathrm{n}} \mathrm{N}$ nitrido ligands bridging two or more metal centers. $[2,10]$ However, a review of the literature shows the lack of systematic studies on the rational construction and reactivity of these aggregates. Polynuclear nitrido complexes might be of particular interest as building blocks in the synthesis of metal nitride materials. ${ }^{[11]}$ Species with $\mu_{\mathrm{n}}$-nitrido groups are also proposed as intermediates in dinitrogen fixation and activation. ${ }^{[12,13,14]}$ Furthermore, polynuclear nitrido complexes have also caught the interest of theoretical chemists. ${ }^{[15]}$

As part of a project devoted to the development of early transition-metal nitrido complexes, in 1995, we reported the synthesis of the first organometallic cube-type nitrido derivative $\left[\left\{\mathrm{Ti}\left(\eta^{5}-\mathrm{C}_{5} \mathrm{Me}_{5}\right)\right\}_{4}\left(\mu_{3}-\mathrm{N}\right)_{4}\right](2)$ by treatment of $\left[\mathrm{Ti}\left(\eta^{5}-\mathrm{C}_{5} \mathrm{Me}_{5}\right)\left(\mathrm{NMe}_{2}\right)_{3}\right]$ with $\mathrm{NH}_{3}$ (Scheme 2). ${ }^{[16,17]}$ Prior to our work, Roesky and co-workers prepared the trinuclear imidonitrido complex $\left[\left\{\mathrm{Ti}\left(\eta^{5}-\mathrm{C}_{5} \mathrm{Me}_{5}\right)(\mu-\mathrm{NH})\right\}_{3}\left(\mu_{3}-\mathrm{N}\right)\right] \quad(\mathbf{1})$ by ammonolysis of $\left[\mathrm{Ti}\left(\eta^{5}-\right.\right.$ $\left.\left.\mathrm{C}_{5} \mathrm{Me}_{5}\right) \mathrm{Me}_{3}\right] .{ }^{[18]}$ 


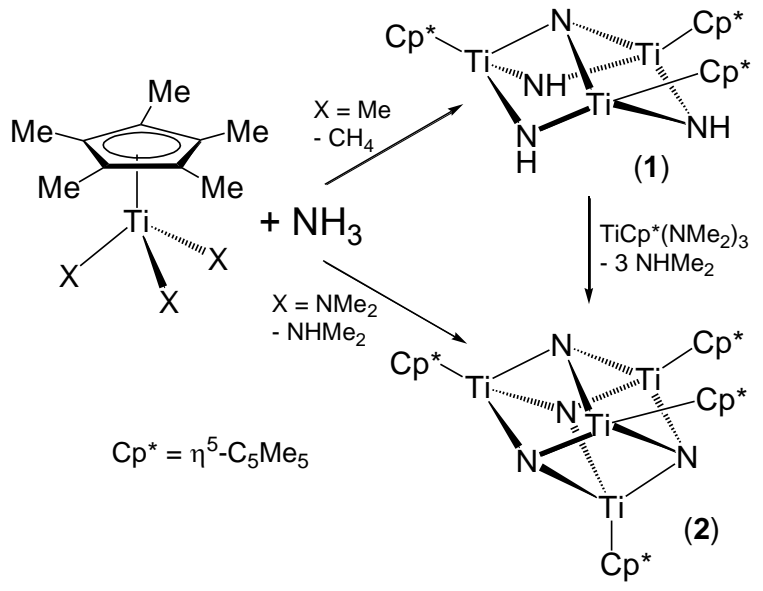

Scheme 2. Syntheses of nitrido complexes $\mathbf{1}$ and $\mathbf{2}$.

The crystal structure of $\mathbf{1}$ revealed an incomplete cube-type $\left[\mathrm{Ti}_{3}(\mu-\mathrm{NH})_{3}\left(\mu_{3}-\mathrm{N}\right)\right]$ core and we have intensively investigated the incorporation of different metal complex fragments to the missed vertex to produce heterometallic cube-type nitrido complexes. Thus, we have reported the coordination of $\mathbf{1}$ by the basal $\mathrm{NH}$ imido groups to transition or main-group metals to give cube-type adducts $\left[\mathrm{L}_{n} \mathrm{M}\left\{\left(\mu_{3}-\mathrm{NH}\right)_{3} \mathrm{Ti}_{3}\left(\eta^{5}-\mathrm{C}_{5} \mathrm{Me}_{5}\right)_{3}\left(\mu_{3}-\mathrm{N}\right)\right\}\right]{ }^{[19]}$ These adducts can undergo activation of the $\mathrm{N}-\mathrm{H}$ bonds of the organometallic ligand $\mathbf{1}$, with elimination of organic molecules $\mathrm{LH}$, and formation of complexes with nitrido groups bridging the metal centers. ${ }^{[20]}$ However, none of those processes involved the triply bridging apical nitrido ligand of 1. Recently, we have reported the first functionalization of the apical nitrido group via an "apparent" nucleophilic attack of an acetylide $\left[\mathrm{C} \equiv \mathrm{CR}^{-}\right]$to give an alkynylimido $\mu_{3}-\mathrm{NCCR}$ ligand by C-N bond formation. ${ }^{[21]}$ Density Functional Theory (DFT) calculations showed that the reaction involves the formation of alkynyl titanium intermediates, and results in a net twoelectron reduction of the $\mathrm{Ti}_{3}$ core.

Herein we describe the first examples of $\mu_{3}-\mathrm{N}$ nitrido ligands behaving as a Lewis base to form adducts with copper(I) and silver(I) [MX] fragments in complexes $\mathbf{1}$ and 2 . DFT calculations have been carried out to understand the formation of these adducts and 
demonstrate that $\mu_{3}-\mathrm{N}$ nitrido ligands act as a true Lewis base and the reaction does not involve reduction of the titanium centers as observed previously.

\section{Results and Discussion}

Treatment of $\left[\left\{\mathrm{Ti}\left(\eta^{5}-\mathrm{C}_{5} \mathrm{Me}_{5}\right)(\mu-\mathrm{NH})\right\}_{3}\left(\mu_{3}-\mathrm{N}\right)\right]$ (1) with one equivalent of anhydrous copper(I) halides $[\mathrm{CuX}]$ or a half equivalent of copper(I) trifluoromethanesulfonate $\left[\left\{\mathrm{Cu}\left(\mathrm{O}_{3} \mathrm{SCF}_{3}\right)\right\}_{2} \cdot \mathrm{C}_{7} \mathrm{H}_{8}\right]$ in toluene or dichloromethane at room temperature gave the cube-type adducts $\left[\mathrm{XCu}\left\{\left(\mu_{3}-\mathrm{NH}\right)_{3} \mathrm{Ti}_{3}\left(\eta^{5}-\mathrm{C}_{5} \mathrm{Me}_{5}\right)_{3}\left(\mu_{3}-\mathrm{N}\right)\right\}\right]\left(\mathrm{X}=\mathrm{Cl}(\mathbf{3}), \mathrm{Br}(\mathbf{4}), \mathrm{I}(\mathbf{5}), \mathrm{OSO}_{2} \mathrm{CF}_{3}(\mathbf{6})\right)$ (Scheme 3). Compounds 3 and 5 have been previously reported. ${ }^{[22]}$ Adducts 3-6 were isolated in $61-86 \%$ yield as air sensitive red or orange solids. Copper halide complexes 3-5 are soluble in toluene or benzene whereas the triflate derivative $\mathbf{6}$ is only soluble in chlorinated solvents.

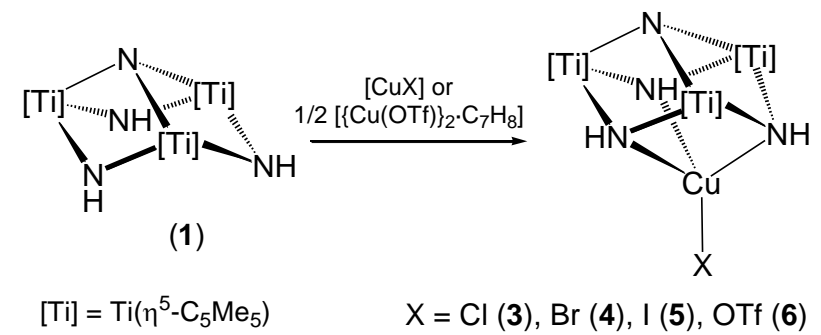

Scheme 3. Reaction of 1 with one equiv of copper(I) reagents.

Compounds 3-6 were characterized by spectral and analytical methods. IR spectra $(\mathrm{KBr})$ of complexes 3-6 show one or two $v_{\mathrm{NH}}$ vibrations, between $3363-3219 \mathrm{~cm}^{-1}$, in a similar range to the value determined for $1,{ }^{[17]} 3352 \mathrm{~cm}^{-1}$. The IR spectrum of 6 reveals several strong absorptions, between 1275 and $1030 \mathrm{~cm}^{-1}$, for the triflate $\mathrm{O}_{3} \mathrm{SCF}_{3}$ fragment. ${ }^{[23]}$ The $v_{\text {as }}\left(\mathrm{SO}_{3}\right)$ vibration splits into two bands at 1272 and $1262 \mathrm{~cm}^{-1}$, indicating interaction of the triflate ion with the copper center in the solid state. ${ }^{[23 c]}{ }^{1} \mathrm{H}$ and ${ }^{13} \mathrm{C}\left\{{ }^{1} \mathrm{H}\right\}$ NMR spectra in $\left[\mathrm{D}_{1}\right]$ chloroform of complexes 3-6 reveal equivalent $\eta^{5}-\mathrm{C}_{5} \mathrm{Me}_{5}$ and $\mathrm{NH}$ groups and are consistent with a $C_{3 v}$ symmetry in solution. The NH resonance signals $(\delta=11.63-11.49)$ are 
shifted toward higher field than that found for $1(\delta=13.40)$, whereas the resonance for the $C_{5} \mathrm{Me}_{5}$ groups $(\delta=120.2-119.6)$ in the ${ }^{13} \mathrm{C}$ NMR spectra are shifted downfield with respect to that found for $1(\delta=117.1)$. The NMR data are similar to those found for other adducts obtained by a tridentate chelate coordination of the basal $\mathrm{NH}$ groups to the metal center. ${ }^{[19]}$ Thus, the tetrahedral environment around the copper center would be comparable to that recently determined by an X-ray crystallographic study for the silver(I) adduct $\left[\mathrm{ClAg}\left\{\left(\mu_{3}-\right.\right.\right.$ $\left.\left.\mathrm{NH})_{3} \mathrm{Ti}_{3}\left(\eta^{5}-\mathrm{C}_{5} \mathrm{Me}_{5}\right)_{3}\left(\mu_{3}-\mathrm{N}\right)\right\}\right] .^{[24]}$

Treatment of $\mathbf{1}$ with two equivalents of copper(I) halides or one equivalent of $\left[\left\{\mathrm{Cu}\left(\mathrm{O}_{3} \mathrm{SCF}_{3}\right)\right\}_{2} \cdot \mathrm{C}_{7} \mathrm{H}_{8}\right]$ in toluene at room temperature for 1-3 days afforded complexes $\left[\mathrm{XCu}\left\{\left(\mu_{3}-\mathrm{NH}\right)_{3} \mathrm{Ti}_{3}\left(\eta^{5}-\mathrm{C}_{5} \mathrm{Me}_{5}\right)_{3}\left(\mu_{4}-\mathrm{N}\right)(\mathrm{CuX})\right\}\right] \quad\left(\mathrm{X}=\mathrm{Cl}(\mathbf{7}), \mathrm{Br}(\mathbf{8}), \mathrm{OSO}_{2} \mathrm{CF}_{3}\right.$ (10)) via incorporation of an additional $[\mathrm{CuX}]$ moiety at the $\mu_{3}-\mathrm{N}$ nitrido apical group (Scheme 4). Compounds 7, 8 and 10 were isolated as red or orange solids in 59-65\% yield after workup. However, the analogous reaction of 1 with excess ( $\geq 2$ equiv) of copper(I) iodide for 4 days gave a red solid with a 60:40 mixture of complexes 5 and $\left[\mathrm{ICu}\left\{\left(\mu_{3}-\mathrm{NH}\right)_{3} \mathrm{Ti}_{3}\left(\eta^{5}-\mathrm{C}_{5} \mathrm{Me}_{5}\right)_{3}\left(\mu_{4}-\right.\right.\right.$ $\mathrm{N})(\mathrm{CuI})\}$ ] (9), according to ${ }^{1} \mathrm{H}$ NMR spectroscopy. Fortunately, crystallization in toluene at $25{ }^{\circ} \mathrm{C}$ gave pure $9 \cdot 3 \mathrm{C}_{7} \mathrm{H}_{8}$, although in low yield (15\%). NMR analysis of the crystals in $\left[\mathrm{D}_{1}\right]$ chloroform revealed an 80:20 mixture of complexes $\mathbf{5}$ and $\mathbf{9}$, indicating the partial dissociation of complex 9 in solution.

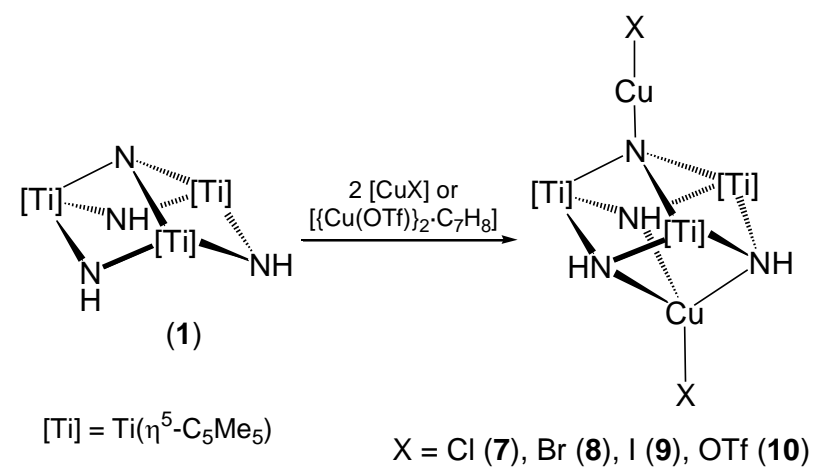

Scheme 4. Reaction of 1 with excess of copper(I) reagents. 
Complexes 7-10 were characterized by analytical and spectroscopic techniques, as well as by X-ray crystal structure determinations for $\mathbf{8 , 9}$ and $\mathbf{1 0}$. IR spectra $(\mathrm{KBr})$ of complexes 710 show one or two $v_{\mathrm{NH}}$ vibrations, between 3360 and $3224 \mathrm{~cm}^{-1}$, in a similar range to the values determined for $\mathbf{1}$ and complexes 3-6. The IR spectrum of $\mathbf{1 0}$ reveals several strong absorptions between 1334 and $1017 \mathrm{~cm}^{-1}$ for the trifluoromethanesulfonate groups. ${ }^{[23]}$ The bands at 1334 and $1311 \mathrm{~cm}^{-1}$, assignable to the $\mathrm{v}_{\mathrm{as}}\left(\mathrm{SO}_{3}\right)$ vibrations, are shifted to higher wavenumbers than that near $1270 \mathrm{~cm}^{-1}$ characteristic of the ionic $\mathrm{CF}_{3} \mathrm{SO}_{3}{ }^{-}{ }^{[23 \mathrm{~b}]}$ and could be indicative of monodentate-bound triflate groups. ${ }^{[23 a]}$ Complex $\mathbf{1 0}$ shows an enhanced solubility in toluene or benzene when compared with $\mathbf{6}$, in good agreement with the IR data. ${ }^{1} \mathrm{H}$ and ${ }^{13} \mathrm{C}\left\{{ }^{1} \mathrm{H}\right\}$ NMR spectra in $\left[\mathrm{D}_{1}\right]$ chloroform of complexes 7-10 reveal resonances for equivalent $\eta^{5}-\mathrm{C}_{5} \mathrm{Me}_{5}$ and $\mathrm{NH}$ groups. The $\mathrm{NH}$ resonance signals $(\delta=11.98-11.95)$ in the ${ }^{1} \mathrm{H}$ NMR spectra are shifted to lower field with respect to those found for complexes 3-6. ${ }^{13} \mathrm{C}\left\{{ }^{1} \mathrm{H}\right\}$ NMR spectra reveal resonance signals for the ipso carbon of the $\eta^{5}-\mathrm{C}_{5} \mathrm{Me}_{5}$ groups $(\delta$ $=124.3-123.1$ ) slightly shifted downfield with respect to those found in 3-6. The NMR data are consistent with a $C_{3 v}$ symmetry in solution, whereas the structures determined in the solidstate for complexes 8-10 are closer to $C_{s}$ symmetry because of the deviation of the $\mathrm{CuX}$ units from the $\mathrm{C}_{3}$ axis that crosses the tripodal ligand.

The molecular structures of $\mathbf{8 - 1 0}$ are shown in Figure 1, while selected distances and angles of the three structures are compared in Table 1. Complexes $\mathbf{8}$ and $\mathbf{9}$ crystallize with one and three toluene molecules, respectively, while crystals of $\mathbf{1 0}$ do not contain solvent molecules. The crystal structures consist of $\left[\mathrm{CuTi}_{3} \mathrm{~N}_{4}\right]$ cube cores, where the metal and nitrogen atoms are positioned on alternating vertices. The copper atoms of the cubes are bound to three imido $\mathrm{NH}$ groups and one terminal halide (8 and 9) or oxygen atom of a trifluoromethanesulfonate group (10). Thus, the coordination geometry of copper(2) is best described as distorted tetrahedral with $\mathrm{N}-\mathrm{Cu}(2)-\mathrm{N}$ angles spanning 91.1(2)-94.3(3) ${ }^{\circ}$ and $\mathrm{N}-$ 
$\mathrm{Cu}(2)-\mathrm{Br} / \mathrm{I} / \mathrm{O}$ angles ranging $111.2(2)-131.4(2)^{\circ}$. On the other side of the cube, the nitrogen(1) atoms are bridging three titanium and one copper atoms. The Ti-N(1) bond lengths in complexes 8-10 (average $1.99 \AA$ ) are very close to the estimated Ti-N single bond distance $(1.981 \AA),{ }^{[25]}$ and are slightly larger than those of the $\mu_{3}-\mathrm{N}$ nitrido groups in $\mathbf{1}$ (average 1.91 $\AA),{ }^{[18]} \mathbf{2}$ (average $1.939 \AA$ ),${ }^{[16]}$ and other cube-type derivatives of $\mathbf{1} .{ }^{[19,20]}$ The small increase of the M-N bond lengths upon coordination of Lewis acids is well-documented in complexes containing terminal nitrido ligands. ${ }_{6}{ }_{6}, 8$ However, the Ti-N(1) distances in 8-10 are shorter than those associated with the alkynylimido ligand $\mu_{3}-\mathrm{NCCSiMe}_{3}$ (average $2.074 \AA$ ) in complex $\left[\left(\mathrm{Me}_{3} \mathrm{SiCC}\right) \mathrm{Zn}\left\{\left(\mu_{3}-\mathrm{NH}\right)_{3} \mathrm{Ti}_{3}\left(\eta^{5}-\mathrm{C}_{5} \mathrm{Me}_{5}\right)_{3}\left(\mu_{3}-\mathrm{NCCSiMe}_{3}\right)\right\}\right],{ }^{[21]}$ where a reduced Ti-N bond order was obtained. In addition, the Ti...Ti distances (average $2.893 \AA$ ) in 8-10 are longer than those determined for that titanium zinc complex (average $2.795 \AA$ ), which showed a two-electron reduction of the $\mathrm{Ti}_{3}$ core occupying a bonding-type molecular orbital according to the DFT analysis of the electronic structure. ${ }^{[21]}$ The $\left\{\left(\mu_{4}-\mathrm{N}\right)(\mathrm{CuX})\right\}$ fragments of the structures are almost linear at copper(1) with angles $\mathrm{N}(1)-\mathrm{Cu}(1)-\mathrm{Br}(1) 178.3(2)^{\circ}(\mathbf{8}), \mathrm{N}(1)-$ $\mathrm{Cu}(1)-\mathrm{I}(1)$ 178.5(2) ${ }^{\circ}(\mathbf{9})$, and $\mathrm{N}(1)-\mathrm{Cu}(1)-\mathrm{O}(1) \quad 166.5(2)^{\circ}(\mathbf{1 0})$. The two-coordinate copper centers show $\mathrm{Cu}(1)-\mathrm{Br} / \mathrm{I} / \mathrm{O}$ bond lengths ca. $0.1 \AA$ shorter than those found for the fourcoordinate $\mathrm{Cu}(2)$. Copper(1) atoms also exhibit very short $\mathrm{Cu}-\mathrm{N}$ distances (1.849(3) (8), $1.841(5)(\mathbf{9}), 1.797(6)(\mathbf{1 0}))$, which are typical for copper complexes with this geometry. ${ }^{[26]}$ 

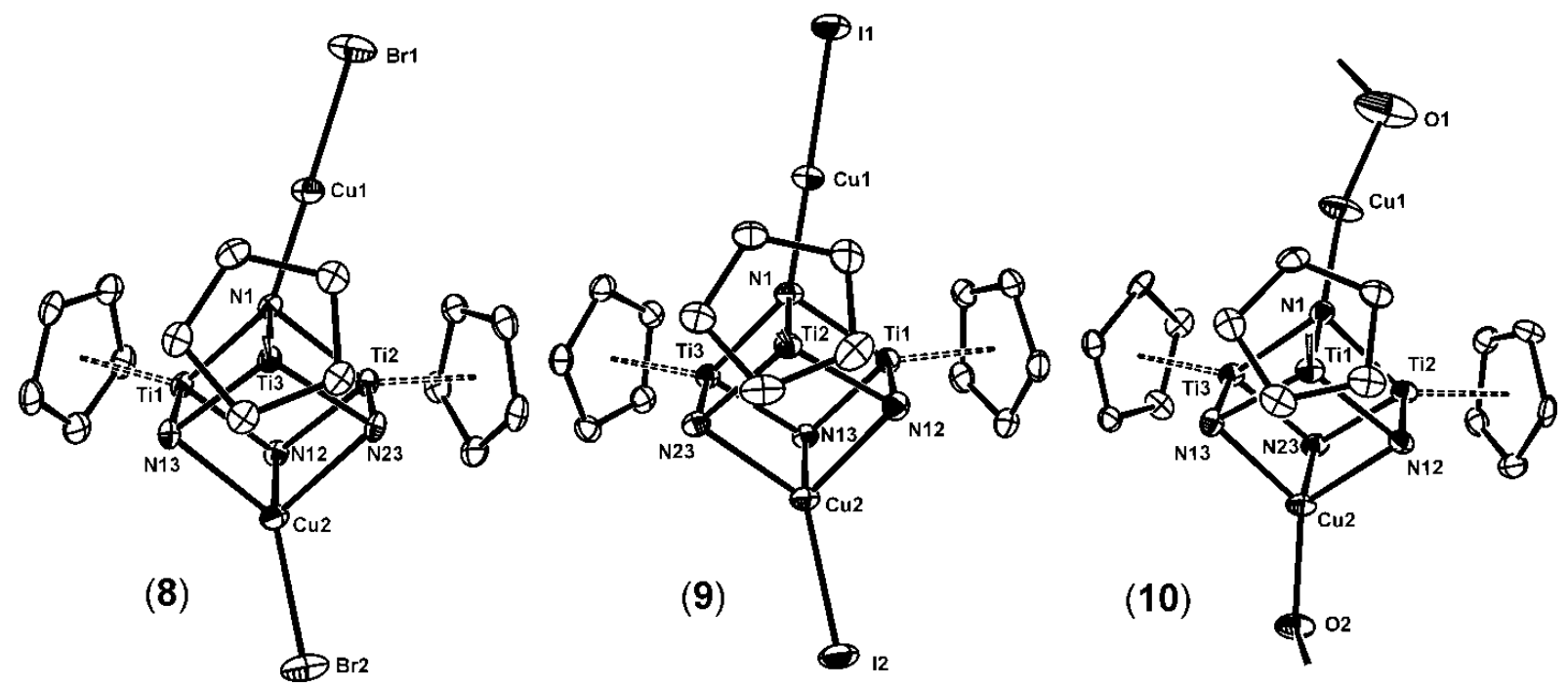

Figure 1. Thermal ellipsoids (30\%) plots of 8-10. The methyl groups of the pentamethylcyclopentadienyl ligands and hydrogen atoms are not shown for clarity. The $\mathrm{SO}_{2} \mathrm{CF}_{3}$ fragments of $\mathbf{1 0}$ are also omitted.

Table 1. Selected lengths $[\AA]$ and angles $\left[^{\circ}\right]$ for complexes $\left[\mathrm{XCu}\left\{\left(\mu_{3}-\mathrm{NH}\right)_{3} \mathrm{Ti}_{3}\left(\eta^{5}-\right.\right.\right.$ $\left.\left.\left.\mathrm{C}_{5} \mathrm{Me}_{5}\right)_{3}\left(\mu_{4}-\mathrm{N}\right) \mathrm{CuX}\right\}\right](\mathbf{8}-\mathbf{1 0})$.

\begin{tabular}{lccccc}
\hline & $\begin{array}{c}\mathbf{8} \\
(\mathrm{X}=\mathrm{Br})\end{array}$ & $\mathbf{D F T ~ 8}^{\prime}\left(\mathbf{C}_{\mathbf{s}}\right)$ & $\mathbf{D F T ~ 8}^{\prime}\left(\mathbf{C}_{\mathbf{3 v}}\right)$ & $\begin{array}{c}\mathbf{9}) \\
(\mathrm{X}=\mathrm{I})\end{array}$ & $\begin{array}{c}\mathbf{1 0} \\
\left(\mathrm{X}=\mathrm{OSO}_{2} \mathrm{CF}_{3}\right)\end{array}$ \\
\hline $\mathrm{Cu}(1)-\mathrm{Br} / \mathrm{I} / \mathrm{O}(1)$ & $2.235(1)$ & 2.287 & 2.289 & $2.401(2)$ & $1.90(3)$ \\
$\mathrm{Cu}(1)-\mathrm{N}(1)$ & $1.849(3)$ & 1.851 & 1.830 & $1.841(5)$ & $1.797(6)$ \\
$\mathrm{Ti}(1)-\mathrm{N}(1)$ & $1.948(3)$ & 1.963 & 1.979 & $1.987(5)$ & $1.990(7)$ \\
$\mathrm{Ti}(2)-\mathrm{N}(1)$ & $2.002(3)$ & 1.996 & 1.979 & $1.994(5)$ & $2.007(7)$ \\
$\mathrm{Ti}(3)-\mathrm{N}(1)$ & $2.009(3)$ & 1.996 & 1.979 & $1.969(5)$ & $2.005(7)$ \\
$\mathrm{Cu}(2)-\mathrm{Br} / \mathrm{I} / \mathrm{O}(2)$ & $2.334(1)$ & 2.376 & 2.358 & $2.498(1)$ & $1.989(6)$ \\
$\mathrm{Cu}(2)-\mathrm{N}(12)$ & $2.095(4)$ & 2.170 & 2.168 & $2.140(5)$ & $2.123(6)$ \\
$\mathrm{Cu}(2)-\mathrm{N}(13)$ & $2.113(3)$ & 2.170 & 2.168 & $2.109(5)$ & $2.109(7)$ \\
$\mathrm{Cu}(2)-\mathrm{N}(23)$ & $2.158(3)$ & 2.161 & 2.168 & $2.123(5)$ & $2.082(6)$ \\
$\mathrm{Ti}(1) \cdots \mathrm{Ti}(2)$ & $2.871(2)$ & 2.895 & 2.898 & $2.896(2)$ & $2.895(2)$ \\
$\mathrm{Ti}(1) \cdots \mathrm{Ti}(3)$ & $2.895(2)$ & 2.895 & 2.898 & $2.887(2)$ & $2.894(2)$ \\
$\mathrm{Ti}(2) \cdots \mathrm{Ti}(3)$ & $2.913(2)$ & 2.906 & 2.898 & $2.880(2)$ & $2.904(2)$ \\
& & & & & \\
$\mathrm{N}(1)-\mathrm{Cu}(1)-\mathrm{Br} / \mathrm{I} / \mathrm{O}(1)$ & $178.3(2)$ & 176.9 & 180.0 & $178.5(2)$ & $166.5(2)$ \\
$\mathrm{Cu}(1)-\mathrm{N}(1)-\mathrm{Ti}(1)$ & $148.1(2)$ & 150.4 & 122.3 & $112.6(3)$ & $131.0(3)$ \\
$\mathrm{Cu}(1)-\mathrm{N}(1)-\mathrm{Ti}(2)$ & $111.1(2)$ & 106.0 & 122.3 & $114.9(2)$ & $115.9(4)$ \\
$\mathrm{Cu}(1)-\mathrm{N}(1)-\mathrm{Ti}(3)$ & $104.5(2)$ & 106.0 & 122.3 & $138.9(3)$ & $122.3(3)$ \\
$\mathrm{N}(12)-\mathrm{Cu}(2)-\mathrm{N}(13)$ & $92.2(2)$ & 90.0 & 89.8 & $91.1(2)$ & $93.9(3)$ \\
$\mathrm{N}(12)-\mathrm{Cu}(2)-\mathrm{N}(23)$ & $91.4(2)$ & 89.6 & 89.8 & $91.9(2)$ & $93.3(3)$ \\
$\mathrm{N}(13)-\mathrm{Cu}(2)-\mathrm{N}(23)$ & $91.4(2)$ & 89.6 & 89.8 & $92.0(2)$ & $94.3(3)$ \\
$\mathrm{N}(12)-\mathrm{Cu}(2)-\mathrm{Br} / \mathrm{I} / \mathrm{O}(2)$ & $131.4(2)$ & 129.8 & 125.4 & $115.2(2)$ & $119.3(3)$ \\
$\mathrm{N}(13)-\mathrm{Cu}(2)-\mathrm{Br} / \mathrm{I} / \mathrm{O}(2)$ & $127.7(2)$ & 123.0 & 125.4 & $128.3(2)$ & $124.9(3)$ \\
$\mathrm{N}(23)-\mathrm{Cu}(2)-\mathrm{Br} / \mathrm{I} / \mathrm{O}(2)$ & $111.2(2)$ & 123.0 & 125.4 & $127.9(2)$ & $123.1(3)$ \\
\hline
\end{tabular}


Density functional theory (DFT) calculations were conducted to understand the electronic structure and formation of these unprecedented adducts $\left[\mathrm{XCu}\left\{\left(\mu_{3}-\mathrm{NH}\right)_{3} \mathrm{Ti}_{3}\left(\eta^{5}-\right.\right.\right.$ $\left.\left.\left.\mathrm{C}_{5} \mathrm{Me}_{5}\right)_{3}\left(\mu_{4}-\mathrm{N}\right)(\mathrm{CuX})\right\}\right]$ (7-10). In calculations, the pentamethylcyclopentadienyl ligands were modeled by cyclopentadienyl groups, assuming a $C_{3 v}$ symmetry for all the species. To back up our methodology, we selected the complex $\left[\mathrm{BrCu}\left\{\left(\mu_{3}-\mathrm{NH}\right)_{3} \mathrm{Ti}_{3}\left(\eta^{5}-\mathrm{C}_{5} \mathrm{H}_{5}\right)_{3}\left(\mu_{4}-\mathrm{N}\right)(\mathrm{CuBr})\right\}\right]$ $\left(\mathbf{8}^{\prime}\right)$. The calculated geometric parameters for $\mathbf{8}^{\prime}$ with $C_{s}$ symmetry are in good agreement with the crystallographic data determined for complex $\mathbf{8}$ and reproduce the distortion of the $\mathrm{CuBr}$ apical unit (Table 1). In the absence of the methyl substituents of cyclopendienyl ligands, the origin of the distortion should not be a steric but an electronic effect (vide infra). The $C_{3 v}$ form is higher in energy than the $C_{s}$ structure by only $4.3 \mathrm{~kJ} \cdot \mathrm{mol}^{-1}$, indicating a low energy barrier for a tilting movement of the copper halide fragments. This low value justifies the behavior of these complexes in the NMR spectra in solution, which is consistent with $C_{3 v}$ symmetry.

We have analyzed the molecular orbital interactions between a $[\mathrm{CuBr}]$ fragment and the basal $\mu-\mathrm{NH}$ imido groups or the apical $\mu_{3}-\mathrm{N}$ nitrido ligand of $\left[\left\{\mathrm{Ti}\left(\eta^{5}-\mathrm{C}_{5} \mathrm{H}_{5}\right)(\mu-\mathrm{NH})\right\}_{3}\left(\mu_{3^{-}}\right.\right.$ N)] (1'). Figure 2 shows the important molecular orbital (MO) interactions for $\left[\mathrm{BrCu}\left\{\left(\mu_{3^{-}}\right.\right.\right.$ $\left.\left.\mathrm{NH})_{3} \mathrm{Ti}_{3}\left(\eta^{5}-\mathrm{C}_{5} \mathrm{H}_{5}\right)_{3}\left(\mu_{3}-\mathrm{N}\right)\right\}\right]\left(\mathbf{4}^{\prime}\right)$ and $\left[\left\{\mathrm{Ti}\left(\eta^{5}-\mathrm{C}_{5} \mathrm{H}_{5}\right)(\mu-\mathrm{NH})\right\}_{3}\left(\mu_{4}-\mathrm{N}\right)(\mathrm{CuBr})\right]\left(\mathbf{4}^{\prime} \mathbf{b}\right)$. 


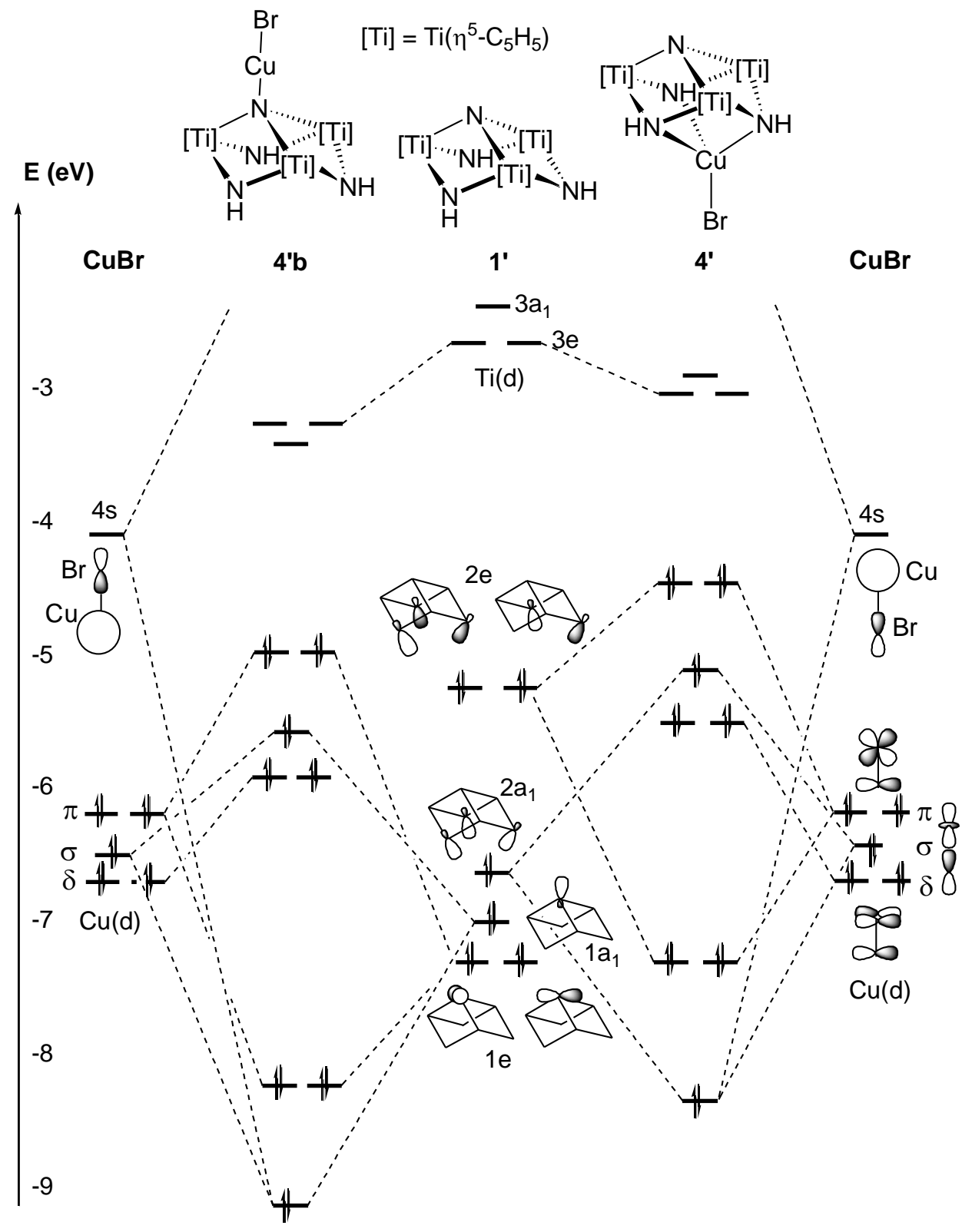

Figure 2. Interaction orbital diagram for complexes 4' and 4'b.

As in previously studied adducts $\left[\mathrm{L}_{n} \mathrm{M}\left\{\left(\mu_{3}-\mathrm{NH}\right)_{3} \mathrm{Ti}_{3}\left(\eta^{5}-\mathrm{C}_{5} \mathrm{H}_{5}\right)_{3}\left(\mu_{3}-\mathrm{N}\right)\right\}\right]$ ( $\mathrm{M}=$ group $4,{ }^{[10]} 6,{ }^{[19 a]}$ and $9^{[19 b]}$ metals), the formation of 4 ' is not accompanied by changes in the oxidation state of the titanium metal centers, being the LUMO a bonding combination of titanium d orbitals. Moreover, the interaction of $\mathrm{CuBr}$ metal fragment with 1' ligand in 4' also arises from stabilization of the molecular orbitals corresponding to the lone pair electrons of the basal imido groups (2e and $2 \mathrm{a}_{1}$ in Figure 2). On the other hand, the highest occupied 
MO's in 4', corresponding to the ten metallic electrons localized on the copper element, show only a small amount of mixing between the copper and the titanium d orbitals. For the five orbitals mentioned the contribution of titanium d orbitals ranges from $3 \%$ to $9 \%$. Thus, we expect a low charge delocalization of the copper $d$ electrons over the compound. In fact, the calculated charge transfer associated with the occupied copper d orbitals for 4' $(0.29$ e) is significantly lower than that calculated for the ionic rhodium(I) and iridium(I) complexes $\left[(\operatorname{cod}) \mathrm{M}\left\{\left(\mu_{3}-\mathrm{NH}\right)_{3} \mathrm{Ti}_{3}\left(\eta^{5}-\mathrm{C}_{5} \mathrm{H}_{5}\right)_{3}\left(\mu_{3}-\mathrm{N}\right)\right\}\right]^{+}\left(0.55\right.$ and 0.72 e) ${ }^{[19 b]}$ The incorporation of the $[\mathrm{CuX}]$ fragments into the basal $\mathrm{NH}$ imido groups of $\mathbf{1}$ ' neither significantly affects to the average bond distances and angles, nor to the electronic structure within the organometallic ligand. For example, the distances between titanium and apical nitrogen lengthen less than $0.01 \AA$ on going from 1 ' to 4'. Furthermore, the multipole atomic charge at the apical nitrido group in 4' increases only about 0.03 a.u. respect to that of 1', reflecting small changes on electronic structure upon incorporation of $\mathrm{CuBr}$ to the basal position of $\mathbf{1}$ '.

In complex 4'b, we have considered that the addition of the copper halide to 1' results in the functionalization of the triply bridging apical nitrido group. A further analysis of the electronic structure of $\mathbf{1}$ ' indicates that there are available molecular orbitals $\left(1 \mathrm{a}_{1}\right.$ and $1 \mathrm{e}$ in Figure 2) to interact with a copper halide fragment via the apical nitrido group. These orbitals lay deeper in energy than those formally corresponding to lone pair electrons of the basal imido groups (2e and 2a $\mathrm{a}_{1}$ ). Moreover, the calculated MO labeled as $1 \mathrm{a}_{1}$ shows a lobe of electron density on the exposed nitrogen atom that can act in a $\sigma$-donor fashion with Lewis acids. The metal-ligand interaction in 4'b arises from the stabilization of $1 \mathrm{a}_{1}$ orbital $(2.2 \mathrm{eV})$, and in minor extension of $1 \mathrm{e}(1.1 \mathrm{eV})$. As observed in 4', the formation of $\mathbf{4}^{\prime} \mathbf{b}$ is not accompanied by changes in oxidation state of titanium centers and shows a still lower metalmetal orbital mixing. Note that we can also observe a repulsive interaction between the filled $\pi$-type orbitals of copper halide fragment and the 1e orbitals. This type of interaction would 
explain the observed distortion of the apical copper halide fragment in complexes 8-10. Thus, the $[\mathrm{CuX}]$ fragment bends out of the $\mathrm{C}_{3}$ axis that crosses the tripodal ligand in order to minimize the repulsive interactions between filled orbitals. For example, on going from the $C_{3 v}$ to $C_{s}$ form in $\mathbf{8}$, the molecular orbital representing the $\pi$-type repulsive interaction between the $\mathrm{CuBr}$ unit and the nitrido group lowers $0.2 \mathrm{eV}$.

We have also evaluated the formation energy of adducts resulting from the coordination of ligand 1' to copper(I) halides $\mathrm{CuX}(\mathrm{X}=\mathrm{Cl}, \mathrm{Br}, \mathrm{I})$, both by the basal imido groups and the apical nitrido ligand (Table 2).

Table 2. Formation energies $\left(\Delta \mathrm{E}, \mathrm{kJ} \cdot \mathrm{mol}^{-1}\right)$ for the coordination of $\left[\left\{\mathrm{Ti}\left(\eta^{5}-\mathrm{C}_{5} \mathrm{H}_{5}\right)(\mu-\right.\right.$ $\left.\mathrm{NH})\}_{3}\left(\mu_{3}-\mathrm{N}\right)\right]\left(\mathbf{1}^{\prime}\right)$ and $\left[\mathrm{XCu}\left\{\left(\mu_{3}-\mathrm{NH}\right)_{3} \mathrm{Ti}_{3}\left(\eta^{5}-\mathrm{C}_{5} \mathrm{H}_{5}\right)_{3}\left(\mu_{3}-\mathrm{N}\right)\right\}\right]$ to $\mathrm{CuX}$, and $\mathrm{Cu}-\mathrm{N}$ Bond distances $[\AA]$.

\begin{tabular}{llccc}
\hline & & basal & $\begin{array}{c}\mathbf{1}^{\prime}+\mathbf{M X} \\
\text { apical }\end{array}$ & $\begin{array}{c}\text { XM(1')+ } \mathbf{M X} \\
\text { apical }\end{array}$ \\
\hline $\mathbf{C u C l}$ & $\Delta \mathrm{E}$ & -207 & -189 & -184 \\
& $\mathrm{~d}(\mathrm{Cu}-\mathrm{N})$ & 2.168 & 1.829 & 1.817 \\
$\mathbf{C u B r}$ & $\Delta \mathrm{E}$ & -206 & -184 & -179 \\
& $\mathrm{~d}(\mathrm{Cu}-\mathrm{N})$ & 2.178 & 1.836 & 1.830 \\
$\mathbf{C u I}$ & $\Delta \mathrm{E}$ & -205 & -174 & -167 \\
& $\mathrm{~d}(\mathrm{Cu}-\mathrm{N})$ & 2.169 & 1.821 & 1.835 \\
\hline
\end{tabular}

The formation of adducts $\left[\mathrm{XCu}\left\{\left(\mu_{3}-\mathrm{NH}\right)_{3} \mathrm{Ti}_{3}\left(\eta^{5}-\mathrm{C}_{5} \mathrm{H}_{5}\right)_{3}\left(\mu_{3}-\mathrm{N}\right)\right\}\right]\left(\mathrm{X}=\mathrm{Cl} \mathbf{3}^{\prime}, \mathrm{Br} 4^{\prime}, \mathrm{I}\right.$ 5') is computed to be a largely exothermic process. The values remain constant on going down in the halogen group (from -207 to $-205 \mathrm{~kJ} \cdot \mathrm{mol}^{-1}$ ). It is worth to compare these results with those previously obtained for other adducts $\left[\mathrm{L}_{n} \mathrm{M}\left\{\left(\mu_{3}-\mathrm{NH}\right)_{3} \mathrm{Ti}_{3}\left(\eta^{5}-\mathrm{C}_{5} \mathrm{H}_{5}\right)_{3}\left(\mu_{3}-\mathrm{N}\right)\right\}\right]($ Table 3). ${ }^{[10,19]}$ It was discussed that the larger formation energies for $\mathrm{d}^{6}$ and $\mathrm{d}^{8}$ metal complexes are a consequence of the non-negligible mixing between the orbitals of the metal center and the $d$ titanium orbitals of the $\mathrm{Ti}_{3} \mathrm{~N}_{3}$ core, whereas for $\mathrm{Ti}$ (IV) without d electrons the formation energy is only due to the metal-ligand interaction. ${ }^{[10]}$ Interestingly, we showed above that in the $\mathrm{d}^{10}$ cooper complex 4 ' the metal-metal orbital mixing and the charge transfer from copper 
to the $\mathrm{Ti}_{3} \mathrm{~N}_{3}$ core is relatively small. Consequently, compounds $\mathbf{3}^{\prime}-\mathbf{5}^{\prime}$ display formation energies similar to those of the Ti(IV) complex (Table 3).

Table 3. Formation energy $(\Delta \mathrm{E})$ for adducts $\left[\mathrm{L}_{n} \mathrm{M}\left\{\left(\mu_{3}-\mathrm{NH}\right)_{3} \mathrm{Ti}_{3}\left(\eta^{5}-\mathrm{C}_{5} \mathrm{H}_{5}\right)_{3}\left(\mu_{3}-\mathrm{N}\right)\right\}\right]$.

\begin{tabular}{lccc}
\hline $\mathbf{L n} \mathbf{M}$ & $\mathbf{M}$ & $\Delta \mathbf{E}\left(\mathbf{k J} \cdot \mathbf{m o l}^{\mathbf{1}}\right)$ & Ref. \\
\hline $\mathrm{Cl}_{2}(\mathrm{PhN}) \mathrm{Ti}$ & $\mathrm{Ti}\left(\mathrm{d}^{0}\right)$ & -203 & {$[10]$} \\
$(\mathrm{CO})_{3} \mathbf{M}$ & $\mathrm{Cr}\left(\mathrm{d}^{6}\right)$ & -376 & {$[19 \mathrm{a}]$} \\
& $\mathrm{Mo}\left(\mathrm{d}^{6}\right)$ & -351 & \\
& $\mathrm{~W}\left(\mathrm{~d}^{6}\right)$ & -445 & {$[19 \mathrm{~b}]$} \\
$(\operatorname{cod}) \mathrm{M}$ & $\mathrm{Rh}\left(\mathrm{d}^{8}\right)$ & -378 & \\
& $\operatorname{Ir}\left(\mathrm{d}^{8}\right)$ & -445 & this work \\
$\mathrm{BrCu}\left(\mathbf{4}^{\prime}\right)$ & $\mathrm{Cu}\left(\mathrm{d}^{10}\right)$ & -206 & \\
\hline
\end{tabular}

In agreement with the experimental results observed in the reaction of $\mathbf{1}$ with one equivalent of copper halide, the calculated coordination energies of ligand 1 ' to $[\mathrm{CuX}]$ fragments through the $\mu_{3}-\mathrm{N}$ apical group to form complexes $\left[\left\{\mathrm{Ti}\left(\eta^{5}-\mathrm{C}_{5} \mathrm{H}_{5}\right)\left(\mu_{3}-\mathrm{NH}\right)\right\}_{3}\left\{\left(\mu_{4}-\right.\right.\right.$ $\mathrm{N})(\mathrm{CuX})\}]\left(\mathrm{X}=\mathrm{Cl} \mathbf{3}^{\prime} \mathbf{b}, \mathrm{Br} \mathbf{4}^{\prime} \mathbf{b}, \mathrm{I}\right.$ 5'b) are lower $\left(-189,-184\right.$, and $-174 \mathrm{~kJ} \cdot \mathrm{mol}^{-1}$, respectively) than those for basal coordination (see Table 2). Nevertheless, the energy differences between basal and apical coordination are not too large $\left(\sim 25 \mathrm{~kJ} \cdot \mathrm{mol}^{-1}\right)$ despite of higher coordination index of cooper in compounds 3'-5'. The small energy difference indicates that the formed copper-nitrogen bonds are stronger in the case of apical coordination. In this line, there is a correlation between the strength of the bond and the copper-nitrogen distances. Thus, for complexes $\mathbf{3}^{\prime} \mathbf{b}-5$ ' $\mathbf{b}$ the $\mathrm{Cu}-\mathrm{N}$ bond distances range from $1.821 \AA$ to $1.836 \AA$, whereas for complexes 3'-5' the values are significantly larger ranging from $2.168 \AA$ to $2.178 \AA$.

One might think that the energy differences between the coordination of $\mathrm{CuX}$ at the basal and apical positions would be larger if the methyl substituents of the cyclopentadienyl ligands were considered because the apical position is more sterically crowded. However, $[\mathrm{CuX}]$ fragments have a linear structure, which may allow them to fit into the apical position of the titanium imido-nitrido ligand. Thus, the pure DFT calculations were combined with hybrid Quantum Mechanics / Molecular Mechanics (QM/MM) calculations on ligand [ $\left\{\mathrm{Ti}\left(\eta^{5}\right.\right.$ - 
$\left.\left.\left.\mathrm{C}_{5} \mathrm{Me}_{5}\right)(\mu-\mathrm{NH})\right\}_{3}\left(\mu_{3}-\mathrm{N}\right)\right]$. The $\mathrm{QM} / \mathrm{MM}$ calculations revealed that upon introduction of the steric effects of methyl substituents the formation energies for apical coordination do not vary significantly (from $-189,-184$ and -174 to $-195,-191$ and $-183 \mathrm{~kJ} \cdot \mathrm{mol}^{-1}$ for $\mathrm{X}=\mathrm{Cl}, \mathrm{Br}$, and $\mathrm{I}$, respectively). Moreover, the energy difference between apical and basal coordination remains very similar, varying from 22 to $20 \mathrm{~kJ} \cdot \mathrm{mol}^{-1}$ in the case of $\mathrm{CuBr}$ fragment. Thus, the preference of coordination of $\mathrm{CuX}$ at the basal position should be of electronic origin. In addition to the higher calculated formation energies, note that the molecular orbitals corresponding to the lone pair of electrons of the basal nitrogens are higher in energy than those MO's corresponding to the lone pair of apical nitrogen (Figure 2).

Once the preference for basal over apical coordination was discussed, we analyzed the observed incorporation of an additional $[\mathrm{CuX}]$ fragment at the $\mu_{3}$-nitrido apical group of compounds 3'-5' to give the model complexes $\left[\mathrm{XCu}\left\{\left(\mu_{3}-\mathrm{NH}\right)_{3} \mathrm{Ti}_{3}\left(\eta^{5}-\mathrm{C}_{5} \mathrm{H}_{5}\right)_{3}\left(\mu_{4}-\mathrm{N}\right)(\mathrm{CuX})\right\}\right]$ $\left(\mathrm{X}=\mathrm{Cl}\left(\mathbf{7}^{\prime}\right), \mathrm{Br}\left(\mathbf{8}^{\prime}\right), \mathrm{I}\left(\mathbf{9}^{\prime}\right)\right)$. The results for calculated formation energies are collected in Table 2. The values are only slightly lower than those computed for the coordination of precubane ligand $\mathbf{1}^{\prime}$ through the apical nitrido group to one $[\mathrm{CuX}]$ unit $\left(\mathbf{3}^{\prime} \mathbf{b}, \mathbf{4}^{\prime} \mathbf{b}, \mathbf{5}^{\prime} \mathbf{b}\right)$. In fact, the molecular orbital interactions between $[\mathrm{CuX}]$ fragments and the corresponding heterocubanes 3'-5' through the apical nitrido to give 7'-9' are very similar to those described above in the formation of $\mathbf{4}^{\prime} \mathbf{b}$ (Figure 2). The incorporation of the [CuX] fragments into the basal $\mathrm{NH}$ imido groups of $\mathbf{1}$ ' neither significantly disturb the electronic structure nor the geometric parameters within the organometallic ligand.

Since the $\mu_{3}$-nitrido ligand of the trinuclear complex $\mathbf{1}$ can act as two-electron donor Lewis base, we have also investigated the possibility of forming adducts with the cube-type titanium nitrido complex $\left[\left\{\mathrm{Ti}\left(\eta^{5}-\mathrm{C}_{5} \mathrm{Me}_{5}\right)\right\}_{4}\left(\mu_{3}-\mathrm{N}\right)_{4}\right]$ (2). The compounds obtained in the treatment of $\mathbf{2}$ with copper(I) halides [CuX] or copper(I) trifluoromethanesulfonate $\left[\left\{\mathrm{Cu}\left(\mathrm{O}_{3} \mathrm{SCF}_{3}\right)\right\}_{2} \cdot \mathrm{C}_{7} \mathrm{H}_{8}\right]$ in different molar ratios are summarized in Scheme 5. The reaction of 
2 with $\mathrm{CuBr}$ ( $\geq 1$ equiv) in toluene at room temperature afforded the incorporation of one [CuBr] fragment to give complex $\left[\left\{\mathrm{Ti}\left(\eta^{5}-\mathrm{C}_{5} \mathrm{Me}_{5}\right)\right\}_{4}\left(\mu_{3}-\mathrm{N}\right)_{3}\left\{\left(\mu_{4}-\mathrm{N}\right) \mathrm{CuBr}\right\}\right]$ (11). Analogous treatment of 2 with $\mathrm{CuCl}\left(\geq 2\right.$ equiv) produced complex $\left[\left\{\mathrm{Ti}\left(\eta^{5}-\mathrm{C}_{5} \mathrm{Me}_{5}\right)\right\}_{4}\left(\mu_{3}-\mathrm{N}\right)_{2}\left\{\left(\mu_{4}-\right.\right.\right.$ $\left.\mathrm{N}) \mathrm{CuCl}\}_{2}\right]$ (12). When 2 was treated with $\left[\left\{\mathrm{Cu}\left(\mathrm{O}_{3} \mathrm{SCF}_{3}\right)\right\}_{2} \cdot \mathrm{C}_{7} \mathrm{H}_{8}\right]$ ( $\geq 1.5$ equiv) complex $\left[\left\{\mathrm{Ti}\left(\eta^{5}-\mathrm{C}_{5} \mathrm{Me}_{5}\right)\right\}_{4}\left(\mu_{3}-\mathrm{N}\right)\left\{\left(\mu_{4}-\mathrm{N}\right) \mathrm{CuOSO}_{2} \mathrm{CF}_{3}\right\}_{3}\right](\mathbf{1 3})$ was obtained.

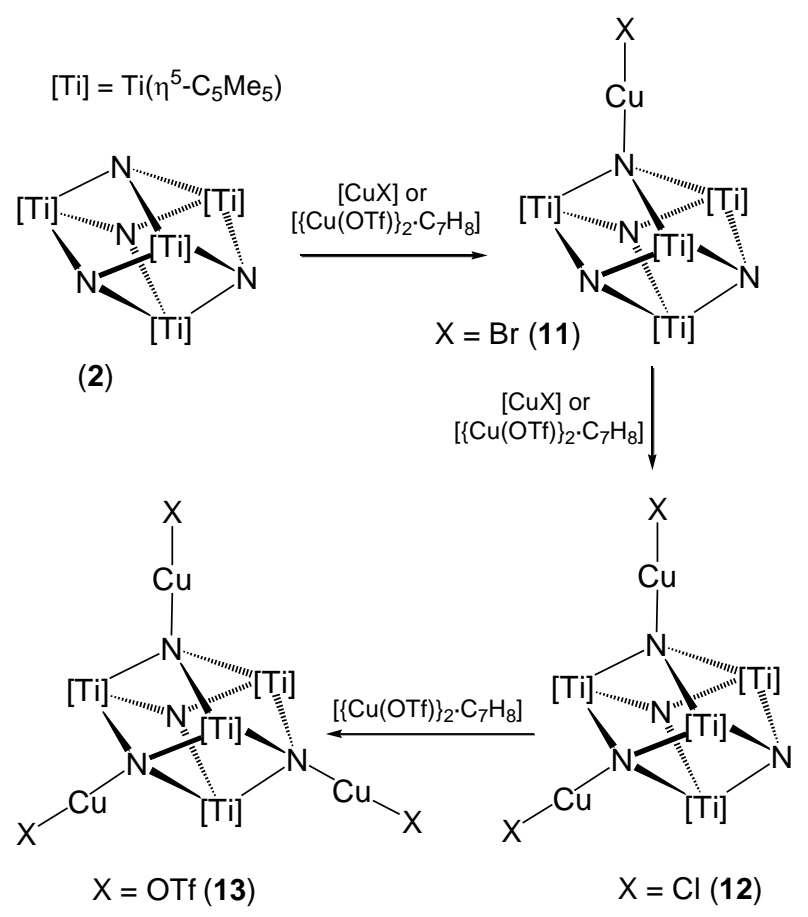

Scheme 5. Reaction of 2 with copper(I) reagents.

Compounds 11-13 were isolated in 49-75\% yield as extremely air sensitive brown solids which are soluble in benzene, toluene or chloroform. Complexes 11-13 were characterized by analytical and spectroscopic methods, as well as by X-ray crystal structure determinations. IR spectra $(\mathrm{KBr})$ show several very strong bands in the range $639-589 \mathrm{~cm}^{-1}$, assignable to the titanium-nitrogen bonds by comparison with that found for $2{ }^{[16]} 644 \mathrm{~cm}^{-1}$. The triflate groups in 13 gave several very strong bands between 1331 and $1011 \mathrm{~cm}^{-1}$, which are similar to those of compound 10. The ${ }^{1} \mathrm{H}$ and ${ }^{13} \mathrm{C}\left\{{ }^{1} \mathrm{H}\right\}$ NMR spectra in $\left[\mathrm{D}_{1}\right]$ chloroform are informative about the number of incorporated $[\mathrm{CuX}]$ fragments. The ${ }^{1} \mathrm{H}$ NMR spectra revealed singlets for two $\eta^{5}-\mathrm{C}_{5} \mathrm{Me}_{5}$ groups in ratios 3:1 (11), 2:2 (12) and 1:3 (13) according with $C_{3 v}(\mathbf{1 1}$ and 13) and 
$C_{s}$ (12) symmetries. The two $C_{5} \mathrm{Me}_{5}$ resonance signals in the ${ }^{13} \mathrm{C}\left\{{ }^{1} \mathrm{H}\right\}$ NMR spectra are shifted downfield with respect to that of complex $2{ }^{[16]} \delta=119.1$. The shifting of these carbon resonances increases with the number of incorporated $[\mathrm{CuX}]$ fragments: $\delta=122.8,121.4$ (11); 126.5, $125.3(\mathbf{1 2})$ and 131.5, 130.6 (13). The NMR data in solution are consistent with the solid-state structures determined by X-ray crystallography (vide infra).

The reaction of $\mathbf{2}$ with different molar ratios of copper(I) reagents in $\left[\mathrm{D}_{1}\right]$ chloroform was examined by NMR spectroscopy. While treatment of 2 with $\mathrm{CuCl}$ ( $\geq 2$ equiv) gave only resonance signals attributable to $\mathbf{1 2}$, when one equivalent of $\mathrm{CuCl}$ is added to $\mathbf{2}$ the NMR spectra revealed a mixture of the $1: 1$ adduct $\left[\left\{\mathrm{Ti}\left(\eta^{5}-\mathrm{C}_{5} \mathrm{Me}_{5}\right)\right\}_{4}\left(\mu_{3}-\mathrm{N}\right)_{3}\left\{\left(\mu_{4}-\mathrm{N}\right) \mathrm{CuCl}\right\}\right]$ and compounds 2 and 12. Analogous reaction of 2 with copper(I) bromide gave only 11, and not further incorporation of $\mathrm{CuBr}$ fragments could be achieved by using an excess of copper reagent. Finally, the treatment of $\mathbf{2}$ with excess of copper(I) iodide gave a 50:50 mixture of $\left[\left\{\mathrm{Ti}\left(\eta^{5}-\mathrm{C}_{5} \mathrm{Me}_{5}\right)\right\}_{4}\left(\mu_{3}-\mathrm{N}\right)_{3}\left\{\left(\mu_{4}-\mathrm{N}\right) \mathrm{CuI}\right\}\right]$ and 2 , even after heating at $50^{\circ} \mathrm{C}$ for 5 days. Similarly, the reaction of 2 with $\left[\left\{\mathrm{Cu}\left(\mathrm{O}_{3} \mathrm{SCF}_{3}\right)\right\}_{2} \cdot \mathrm{C}_{7} \mathrm{H}_{8}\right]$ in 1:0.5 and 1:1 molar ratios allowed the identification by NMR spectroscopy of intermediates $\left[\left\{\mathrm{Ti}\left(\eta^{5}-\mathrm{C}_{5} \mathrm{Me}_{5}\right)\right\}_{4}\left(\mu_{3}-\mathrm{N}\right)_{3}\left\{\left(\mu_{4}-\right.\right.\right.$ $\left.\left.\mathrm{N}) \mathrm{CuOSO}_{2} \mathrm{CF}_{3}\right\}\right]$ and $\left[\left\{\mathrm{Ti}\left(\eta^{5}-\mathrm{C}_{5} \mathrm{Me}_{5}\right)\right\}_{4}\left(\mu_{3}-\mathrm{N}\right)_{2}\left\{\left(\mu_{4}-\mathrm{N}\right) \mathrm{CuOSO}_{2} \mathrm{CF}_{3}\right\}_{2}\right]$ in the formation of $\mathbf{1 3}$. Although none of these adducts $\left[\left\{\operatorname{Ti}\left(\eta^{5}-\mathrm{C}_{5} \mathrm{Me}_{5}\right)\right\}_{4}\left(\mu_{3}-\mathrm{N}\right)_{4-\mathrm{n}}\left\{\left(\mu_{4}-\mathrm{N}\right) \mathrm{CuX}\right\}_{\mathrm{n}}\right](\mathrm{n}=1, \mathrm{X}=\mathrm{Cl}, \mathrm{I}$, $\left.\mathrm{OSO}_{2} \mathrm{CF}_{3} ; \mathrm{n}=2, \mathrm{X}=\mathrm{OSO}_{2} \mathrm{CF}_{3}\right)$ was isolated in a pure form, their ${ }^{1} \mathrm{H}$ and ${ }^{13} \mathrm{C}\left\{{ }^{1} \mathrm{H}\right\} \mathrm{NMR}$ data in $\left[\mathrm{D}_{1}\right]$ chloroform agree with the symmetries and chemical shifts described above for compounds 11-13. ${ }^{[27]}$

The molecular structures of 11-13 are shown in Figure 3, while selected lengths and angles of the three structures are compared in Table 4. Complexes $\mathbf{1 1}$ and $\mathbf{1 2}$ crystallize with two independent molecules in the asymmetric units and bear one toluene molecule per independent unit. Crystals of $\mathbf{1 3}$ contain two toluene solvent molecules per cube-type compound. The crystal structures consist of almost perfect $\left[\mathrm{Ti}_{4} \mathrm{~N}_{4}\right]$ cube cores, with all Ti-N- 
Ti and N-Ti-N angles close to $90^{\circ}$, in a fashion similar to the parent compound $2 .{ }^{[16]}$ Each titanium atom is bound to one $\eta^{5}-\mathrm{C}_{5} \mathrm{Me}_{5}$ ligand and three bridging nitrido groups. The coordination of $\mathrm{CuX}$ to the $\mu_{3}-\mathrm{N}$ groups results in a slight lengthening, ca. $0.05 \AA$, of the titanium-nitrogen distances of the $\left\{\mathrm{Ti}_{3}\left(\mu_{4}-\mathrm{N}\right) \mathrm{CuX}\right\}$ fragments when compared with the Ti-N of the $\left\{\mathrm{Ti}_{3}\left(\mu_{3}-\mathrm{N}\right)\right\}$ units (average $\left.1.95 \AA\right)$. The $\left\{\left(\mu_{4}-\mathrm{N}\right) \mathrm{CuX}\right\}$ fragments in complexes 11-13 are very similar to those described above for the crystal structures of $\mathbf{8 - 1 0}$. Thus, the copper atoms show a linear geometry (average angles $\mathrm{N}-\mathrm{Cu}-\mathrm{Br} / \mathrm{Cl} / \mathrm{O}$ of $178.5(8)^{\circ}(\mathbf{1 1}), 179.1(6)^{\circ}(\mathbf{1 2})$ and $175.2(5)^{\circ}(\mathbf{1 3})$ ) with short $\mathrm{Cu}-\mathrm{Br} / \mathrm{Cl} / \mathrm{O}$ and $\mathrm{Cu}-\mathrm{N}$ bond lengths typical for two-coordinate copper(I) complexes. ${ }^{[26]}$

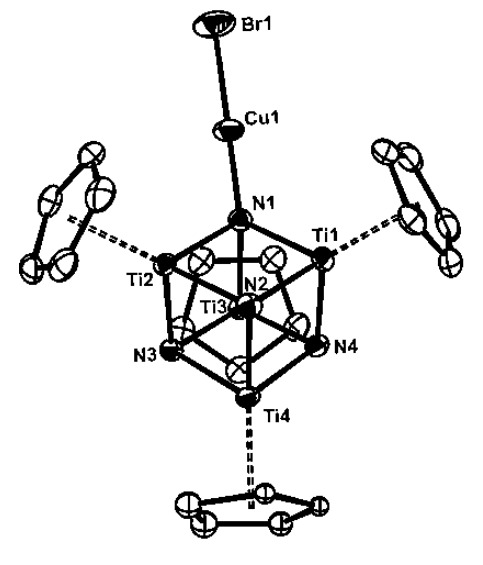

(11)

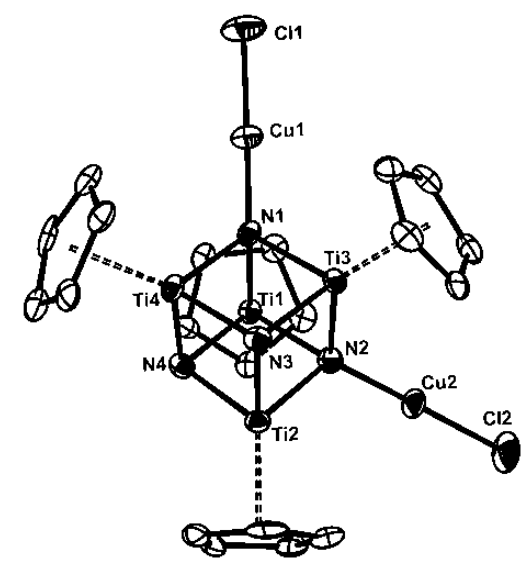

(12)

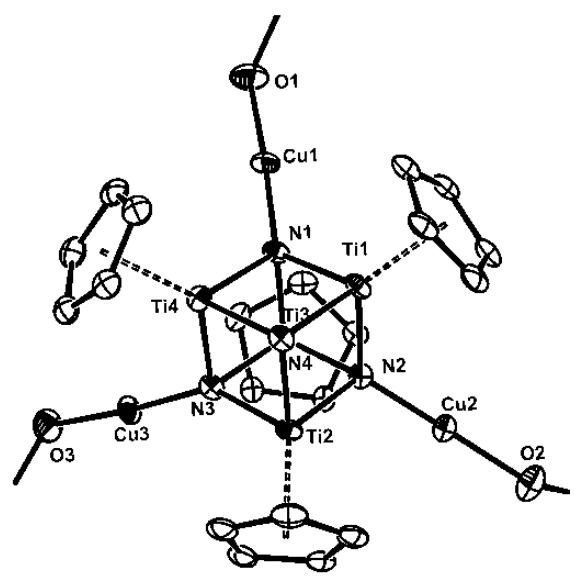

(13)

Figure 3. Thermal ellipsoids (30\%) plots of 11-13. The methyl groups of the pentamethylcyclopentadienyl ligands are not shown for clarity. The $\mathrm{SO}_{2} \mathrm{CF}_{3}$ fragments of $\mathbf{1 3}$ are also omitted. 
Table 4. Selected average lengths $[\AA ̊]$ and angles $\left[{ }^{\circ}\right]$ for complexes $\left[\left\{\operatorname{Ti}\left(\eta^{5}-\mathrm{C}_{5} \mathrm{Me}_{5}\right)\right\}_{4}\left(\mu_{3}-\mathrm{N}\right)_{4-}\right.$ $\left.{ }_{n}\left\{\left(\mu_{4}-\mathrm{N}\right) \mathrm{CuX}\right\}_{n}\right](\mathbf{1 1 - 1 3})$.

\begin{tabular}{lccc}
\hline & $\mathbf{1 1}, \mathrm{n}=1^{a}$ & $\mathbf{1 2}, \mathrm{n}=2^{a}$ & $\mathbf{1 3}, \mathrm{n}=3$ \\
$\mathrm{X}=\mathrm{Br}$ & $\mathrm{X}=\mathrm{Cl}$ & $\mathrm{X}=\mathrm{OSO}_{2} \mathrm{CF}_{3}$ \\
\hline $\mathrm{Cu}-\mathrm{Br} / \mathrm{Cl} / \mathrm{O}$ & $2.250(5)$ & $2.128(3)$ & $1.890(4)$ \\
$\mathrm{Cu}-\mathrm{N}$ & $1.840(18)$ & $1.849(6)$ & $1.836(8)$ \\
$\mathrm{Ti}-\mathrm{N}\left(\mu_{4}\right)$ & $2.007(11)$ & $2.003(11)$ & $2.009(11)$ \\
$\mathrm{Ti}-\mathrm{N}\left(\mu_{3}\right)$ & $1.953(13)$ & $1.951(14)$ & $1.951(10)$ \\
$\mathrm{Ti} \cdots \mathrm{Ti}$ & $2.816(2)-2.875(2)$ & $2.830(2)-2.902(2)$ & $2.865(2)-2.934(2)$ \\
& & & \\
$\mathrm{N}-\mathrm{Cu}-\mathrm{Br} / \mathrm{Cl} / \mathrm{O}$ & $178.5(8)$ & $179.1(6)$ & $175.2(5)$ \\
$\mathrm{Cu}-\mathrm{N}-\mathrm{Ti}$ & $118.5(2)-131.5(3)$ & $115.7(3)-137.4(3)$ & $111.3(2)-142.0(2)-$ \\
$\mathrm{Ti}-\mathrm{N}\left(\mu_{4}\right)-\mathrm{Ti}$ & $90.8(1)$ & $91.7(9)$ & $92.5(11)$ \\
$\mathrm{Ti}-\mathrm{N}\left(\mu_{3}\right)-\mathrm{Ti}$ & $93.1(11)$ & $93.8(10)$ & $94.72(12)$ \\
$\mathrm{N}-\mathrm{Ti}-\mathrm{N}$ & $87.4(4)$ & $87.2(5)$ & $86.9(3)$ \\
\hline
\end{tabular}

[a] Averaged values for the two independent molecules in the asymmetric unit.

We have also theoretically analyzed the nature and strengths of the interactions of $\mu_{3}-$ nitrido ligands of $\mathbf{2}$ with [MX] units, and the ability of complex $\mathbf{2}$ to incorporate several Lewis acids. DFT calculations were carried out on the model complex $\left[\left\{\operatorname{Ti}\left(\eta^{5}-\mathrm{C}_{5} \mathrm{H}_{5}\right)\right\}_{4}\left(\mu_{3}-\mathrm{N}\right)_{4}\right]\left(\mathbf{2}^{\prime}\right)$. We considered $[\mathrm{CuX}]\left(\mathrm{X}=\mathrm{OSO}_{2} \mathrm{CF}_{3}, \mathrm{Cl}, \mathrm{Br}, \mathrm{I}\right)$ and $[\mathrm{AgX}]\left(\mathrm{X}=\mathrm{OSO}_{2} \mathrm{CF}_{3}, \mathrm{Cl}\right)$ fragments, and the incorporation of one, two, three, and four units to complex 2'. Figure 4 gives the formation energies for the successive addition of $[\mathrm{MX}]$ fragments to 2'. In all cases, the addition of one MX unit to [2'-(MX) $)^{\prime}(\mathrm{n}=0,1,2$, and 3) is a largely exothermic process (from -98 to $-233 \mathrm{~kJ} \cdot \mathrm{mol}^{-1}$ ). These values are larger for copper trifluoromethanesulfonate than for copper halides, and within the copper halides the exothermicity decreases going down the halogen group. The DFT results are consistent with the trends observed experimentally, the larger formation energy, $\mathrm{Cu}\left(\mathrm{OSO}_{2} \mathrm{CF}_{3}\right)>\mathrm{CuCl}>\mathrm{CuBr}>\mathrm{CuI}$, the more $[\mathrm{CuX}]$ units bound to the tetranuclear titanium cube-type nitrido derivative 2 were observed $(3,2,1$, and 0 for $\mathrm{Cu}\left(\mathrm{OSO}_{2} \mathrm{CF}_{3}\right), \mathrm{CuCl}, \mathrm{CuBr}$, and $\mathrm{CuI}$, respectively). As detailed below, the $[\mathrm{AgX}]$ fragments experimentally show less tendency to bound the titanium nitrido complex $\mathbf{2}$ ( 1 and 0 units for 
$\mathrm{Ag}\left(\mathrm{OSO}_{2} \mathrm{CF}_{3}\right)$ and $\mathrm{AgCl}$, respectively); and accordantly, the calculated formation energies are lower for silver compounds.

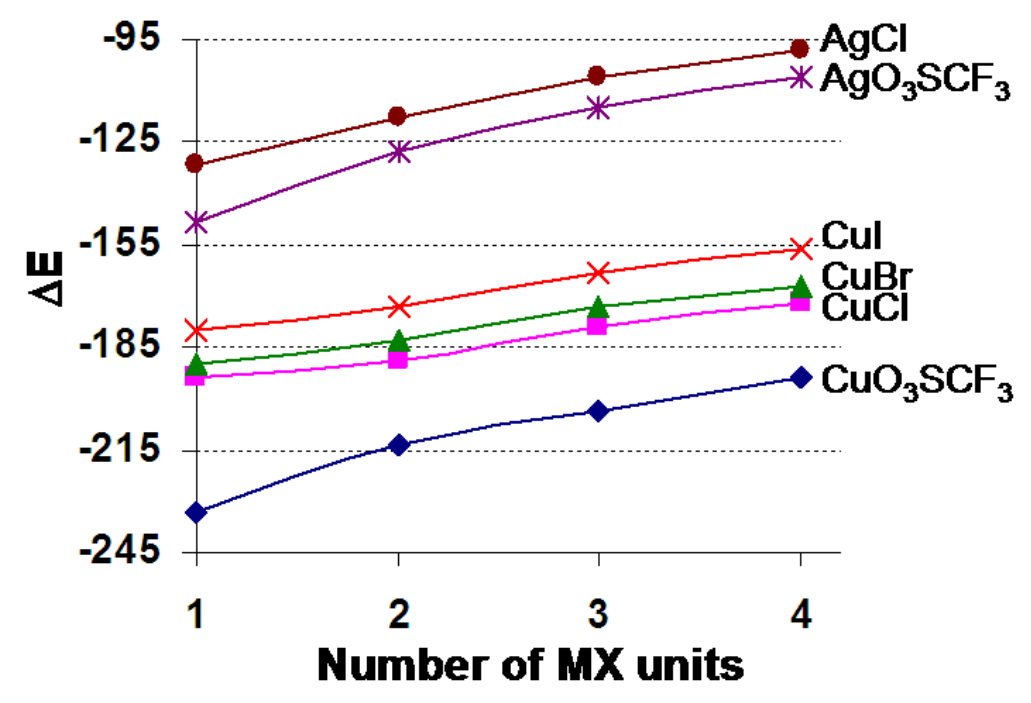

Figure 4. Calculated formation energies $\left(\Delta \mathrm{E}, \mathrm{kJ} \cdot \mathrm{mol}^{-1}\right)$ for the successive coordination of [MX] units $\left(\mathrm{M}=\mathrm{Cu}, \mathrm{Ag} ; \mathrm{X}=\mathrm{Cl}, \mathrm{Br}, \mathrm{I}, \mathrm{OSO}_{2} \mathrm{CF}_{3}\right)$ to 2'.

We also observed that the exothermicity of the addition decreases as the number of [MX] units added to complex 2' increases (see Figure 4). Nevertheless, the formation energy differences between two successive additions of copper or silver inorganic fragments vary in a small amount, about $7-10 \quad \mathrm{~kJ} \cdot \mathrm{mol}^{-1}$, except for the second addition in trifluoromethanesulfonate metal units $\left(20 \mathrm{~kJ} \cdot \mathrm{mol}^{-1}\right)$. This means that coordination of one $\mathrm{d}^{10}$ metal inorganic fragment does not dramatically reduce the Lewis basicity of the remaining $\mu_{3^{-}}$ nitrido groups of the titanium cube compound. Note also that even upon addition of a fourth unit the computed formation energy values are largely exothermic ranging from -194 to -156 $\mathrm{kJ} \cdot \mathrm{mol}^{-1}$ for $[\mathrm{CuX}]$ fragments, and from -106 to $-98 \mathrm{~kJ} \cdot \mathrm{mol}^{-1}$ for $[\mathrm{AgX}]$ units. These latter results cannot completely explain why the maximum number of $[\mathrm{CuX}]$ fragments added to 2 was only three. In fact, our calculation energies were done in vacuum, and formation energies correspond to the addition of two isolated molecular fragments. In the experiments the 
reactions were carried out with the copper reagents in the solid state, and therefore the dissolution of the copper salts must also be taken into account in the energetic balance. Because the dissolution energy is always positive, the real-world reaction process should be less exothermic than those computed in vacuum, or even endothermic. ${ }^{[19 c]}$ Although absolute energy values must be discussed with care, the trends within the series of metal inorganic fragments provide valuable information.

For the addition of one unit of copper halide to 2', the computed formation energy values range from -194 to $-180 \mathrm{~kJ} \cdot \mathrm{mol}^{-1}$, and the copper-nitrogen distances range from 1.824 to $1.840 \AA$. These calculated $\mathrm{Cu}-\mathrm{N}$ lengths compare well with that determined by $\mathrm{X}$-ray crystallography for complex 11, average $1.840(18) \AA$. The formation energies and $\mathrm{Cu}-\mathrm{N}$ distances are very similar to those computed for the apical addition to the ligand 1' (see Table 2), indicating that in both cases the interaction of $\mu_{3}$-nitrido ligands with $[\mathrm{CuX}]$ units is similar in nature. For all the $\left[\mathbf{2}^{\prime}-(\mathrm{CuX})_{n}\right]$ adducts the LUMO corresponds to a bonding combination of titanium d orbitals, while the highest occupied molecular orbitals corresponds to the metallic electrons localized on the copper atom. Lying deeper in energy, there is a set of molecular orbitals formally corresponding to the lone pair electrons of the triply bridging nitrido groups. A similar situation is also observed for [2'-( $\left.\mathrm{AgX})_{\mathrm{n}}\right]$ adducts.

Theoretical calculations indicate that the interactions of the $\mu_{3}$-nitrido groups with silver(I) $[\mathrm{AgX}]$ fragments were also exothermic, although with significantly lower values when compared to $[\mathrm{CuX}]$ units. Thus, we tried the synthesis of adducts of $\mathbf{1}$ and $\mathbf{2}$ with silver(I) halides and silver(I) trifluoromethanesulfonate. Complex $\mathbf{1}$ coordinates one equivalent of $[\mathrm{AgX}]$ at the basal position to give cube-type adducts $\left[\mathrm{XAg}\left\{\left(\mu_{3}-\mathrm{NH}\right)_{3} \mathrm{Ti}_{3}\left(\eta^{5}-\right.\right.\right.$ $\left.\left.\left.\mathrm{C}_{5} \mathrm{Me}_{5}\right)_{3}\left(\mu_{3}-\mathrm{N}\right)\right\}\right] \quad\left(\mathrm{X}=\mathrm{Cl}^{[24]}{ }^{\mathrm{I},{ }^{[24]}} \mathrm{OSO}_{2} \mathrm{CF}_{3}{ }^{[28]}\right)$. However, NMR experiments in $\left[\mathrm{D}_{1}\right]$ chloroform showed that $\left[\mathrm{ClAg}\left\{\left(\mu_{3}-\mathrm{NH}\right)_{3} \mathrm{Ti}_{3}\left(\eta^{5}-\mathrm{C}_{5} \mathrm{Me}_{5}\right)_{3}\left(\mu_{3}-\mathrm{N}\right)\right\}\right]$ does not incorporate additional $\mathrm{AgCl}$ fragments and reacts with $\mathrm{CuCl}$ to give complex 3 via exchange of the [MX] 
fragment at the basal position. Furthermore, the silver(I) triflate adduct $\left[\left(\mathrm{CF}_{3} \mathrm{SO}_{2} \mathrm{O}\right) \mathrm{Ag}\left\{\left(\mu_{3}-\right.\right.\right.$ $\left.\left.\mathrm{NH})_{3} \mathrm{Ti}_{3}\left(\eta^{5}-\mathrm{C}_{5} \mathrm{Me}_{5}\right)_{3}\left(\mu_{3}-\mathrm{N}\right)\right\}\right]$ reacts with excess of $\left[\mathrm{Ag}\left(\mathrm{O}_{3} \mathrm{SCF}_{3}\right)\right]$ to give the triangular silver cluster $\left[\left(\mathrm{CF}_{3} \mathrm{SO}_{2} \mathrm{O}\right)_{3} \mathrm{Ag}_{3}\left\{\left(\mu_{3}-\mathrm{NH}\right)_{3} \mathrm{Ti}_{3}\left(\eta^{5}-\mathrm{C}_{5} \mathrm{Me}_{5}\right)_{3}\left(\mu_{3}-\mathrm{N}\right)\right\}_{2}\right]$ without participation of the $\mu_{3}-\mathrm{N}$ ligands. ${ }^{[28]}$

Similarly, complex 2 does not react with $\mathrm{AgCl}$ in $\left[\mathrm{D}_{1}\right]$ chloroform even at high temperatures. However, treatment of $\mathbf{2}$ with silver(I) trifluoromethanesulfonate ( $\geq 1$ equiv) in toluene at room temperature gave the adduct $\left[\left\{\mathrm{Ti}\left(\eta^{5}-\mathrm{C}_{5} \mathrm{Me}_{5}\right)\right\}_{4}\left(\mu_{3}-\mathrm{N}\right)_{3}\left\{\left(\mu_{4}-\mathrm{N}\right) \mathrm{AgOSO}_{2} \mathrm{CF}_{3}\right\}\right]$ (14) (Scheme 6). No further incorporation of $\left[\mathrm{AgOSO}_{2} \mathrm{CF}_{3}\right]$ fragments was observed in NMR experiments.

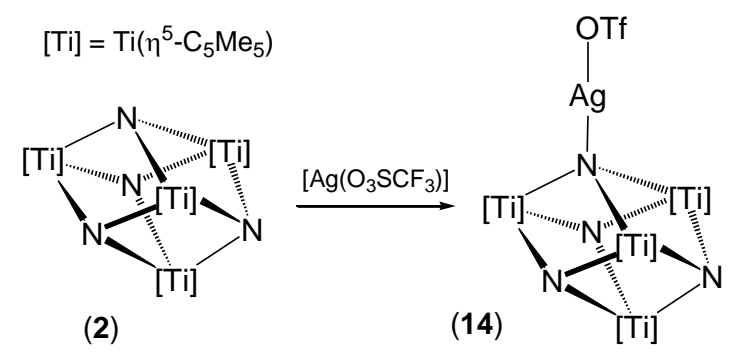

Scheme 6. Reaction of 2 with $\left[\mathrm{Ag}\left(\mathrm{O}_{3} \mathrm{SCF}_{3}\right)\right]$.

Complex 14 was isolated in 58\% yield as an air and light sensitive brown solid, which is soluble in benzene, toluene or halogenated solvents. Spectroscopic data for complex $\mathbf{1 4}$ are fully consistent with those expected for a $C_{3 v}$ symmetry in solution. 


\section{Conclusion}

The reactions described herein have demonstrated the ability of the $\mu_{3}$-nitrido ligands of complexes $\left[\left\{\mathrm{Ti}\left(\eta^{5}-\mathrm{C}_{5} \mathrm{Me}_{5}\right)(\mu-\mathrm{NH})\right\}_{3}\left(\mu_{3}-\mathrm{N}\right)\right](\mathbf{1})$ and $\left[\left\{\mathrm{Ti}\left(\eta^{5}-\mathrm{C}_{5} \mathrm{Me}_{5}\right)\right\}_{4}\left(\mu_{3}-\mathrm{N}\right)_{4}\right]$ (2) to form adducts with copper(I) or silver(I) $[\mathrm{MX}]$ fragments. DFT calculations have shown that the reactions are energetically favorable although the interaction energies are lower than those associated with the coordination through the basal imido groups of $\mathbf{1}$. The two titanium polynuclear complexes can act as two-electron donor Lewis bases through the $\mu_{3}$-nitrido groups without changing the oxidation state of the titanium centers. Moreover, addition of MX units to $\left[\left\{\mathrm{Ti}\left(\eta^{5}-\mathrm{C}_{5} \mathrm{Me}_{5}\right)\right\}_{4}\left(\mu_{3}-\mathrm{N}\right)_{4}\right](2)$ do not significantly reduce the Lewis basicity of the remaining $\mu_{3}$-nitrido groups. Thus, the tetranuclear titanium derivative $\mathbf{2}$ is capable of incorporating one, two or up to three $[\mathrm{CuX}]$ fragments. In the future we hope to expand this study with other inorganic combinations with the aim to uncover more novel findings in the area of metal nitrido complexes. 


\section{Experimental Section}

General Considerations. All manipulations were carried out under argon atmosphere using Schlenk line or glovebox techniques. Hexane and toluene were distilled from $\mathrm{Na} / \mathrm{K}$ alloy just before use. Dichloromethane was dried with $\mathrm{P}_{2} \mathrm{O}_{5}$ and distilled prior to use. NMR solvents were dried with $\mathrm{Na} / \mathrm{K}$ alloy $\left(\mathrm{C}_{6} \mathrm{D}_{6}\right)$ or calcium hydride $\left(\mathrm{CDCl}_{3}\right)$ and vacuum-distilled. Ovendried glassware was repeatedly evacuated with a pumping system (ca. $1 \times 10^{-3}$ Torr) and subsequently filled with inert gas. Anhydrous copper(I) halides $[\mathrm{CuX}](\mathrm{X}=\mathrm{Cl}, \mathrm{Br}, \mathrm{I})$, $\left[\left\{\mathrm{Cu}\left(\mathrm{O}_{3} \mathrm{SCF}_{3}\right)\right\}_{2} \cdot \mathrm{C}_{7} \mathrm{H}_{8}\right]$ and $\left[\mathrm{Ag}\left(\mathrm{O}_{3} \mathrm{SCF}_{3}\right)\right]$ were purchased from Aldrich and used as received. $\left[\left\{\mathrm{Ti}\left(\eta^{5}-\mathrm{C}_{5} \mathrm{Me}_{5}\right)(\mu-\mathrm{NH})\right\}_{3}\left(\mu_{3}-\mathrm{N}\right)\right]^{[18]}(\mathbf{1})$ and $\left[\left\{\mathrm{Ti}\left(\eta^{5}-\mathrm{C}_{5} \mathrm{Me}_{5}\right)\right\}_{4}\left(\mu_{3}-\mathrm{N}\right)_{4}\right]^{[16]}$ (2) were prepared according to published procedures.

Samples for infrared spectroscopy were prepared as $\mathrm{KBr}$ pellets. ${ }^{1} \mathrm{H},{ }^{19} \mathrm{~F}$ and ${ }^{13} \mathrm{C}\left\{{ }^{1} \mathrm{H}\right\} \mathrm{NMR}$ spectra were recorded on a Varian Unity-300 and/or Mercury-300 spectrometer. Chemical shifts $(\delta)$ in the ${ }^{1} \mathrm{H}$ and ${ }^{13} \mathrm{C}\left\{{ }^{1} \mathrm{H}\right\}$ NMR spectra are given relative to residual protons or to carbon of the solvent. Chemical shifts $(\delta)$ in the ${ }^{19} \mathrm{~F}$ NMR spectra are given relative to $\mathrm{CFCl}_{3}$ as external reference. Microanalyses $(\mathrm{C}, \mathrm{H}, \mathrm{N}, \mathrm{S})$ were performed in a Leco CHNS-932 microanalyzer.

Synthesis of $\left[\mathrm{BrCu}\left\{\left(\mu_{3}-\mathbf{N H}\right)_{3} \mathbf{T i}_{3}\left(\eta^{5}-\mathrm{C}_{5} \mathbf{M e}_{3}\right)_{3}\left(\mu_{3}-\mathrm{N}\right)\right\}\right]$ (4). A $100 \mathrm{~mL}$ Schlenk flask was charged with 1 (0.30 g, $0.49 \mathrm{mmol}), \mathrm{CuBr}(0.07 \mathrm{~g}, 0.49 \mathrm{mmol})$ and toluene $(30 \mathrm{~mL})$. The reaction mixture was stirred at room temperature for $5 \mathrm{~h}$ to give a red solution. After filtration, the volatile components were removed under reduced pressure to give $\mathbf{4}$ as a red powder $(0.32$ g, 86\%). ${ }^{1} \mathrm{H}$ NMR (300 MHz, $\left.\mathrm{CDCl}_{3}, 20{ }^{\circ} \mathrm{C}, \mathrm{TMS}\right): \delta=11.62$ (s broad, 3H; $\mathrm{NH}$ ), $2.02 \mathrm{ppm}$ (s, 45H; $\left.\mathrm{C}_{5} \mathrm{Me}_{5}\right) ;{ }^{13} \mathrm{C}\left\{{ }^{1} \mathrm{H}\right\} \mathrm{NMR}\left(75 \mathrm{MHz}, \mathrm{CDCl}_{3}, 20{ }^{\circ} \mathrm{C}, \mathrm{TMS}\right): \delta=119.7\left(C_{5} \mathrm{Me}_{5}\right), 11.7$ ppm ( $\left.\mathrm{C}_{5} \mathrm{Me}_{5}\right)$; IR (KBr): $\tilde{v}=3362$ (m), 3246 (broad, m), 2908 (s), 2856 (m), 2723 (w), 1489 (m), 1428 (s), 1376 (s), $1261(w), 1065$ (w), 1023 (m), 952 (w), 918 (w), 789 (s), 750 (s), 643 
(vs), 518 (w), 475 (w), 427 (s), 400 (s) cm $\mathrm{cm}^{-1}$; elemental analysis calcd (\%) for $\mathrm{C}_{30} \mathrm{H}_{48} \mathrm{BrCuN}_{4} \mathrm{Ti}_{3}\left(M_{w}=751.79\right):$ C 47.93, H 6.44, N 7.45; found: C 48.51, H 6.40, N 6.94. The synthesis and characterization of complexes $\left[\mathrm{XCu}\left\{\left(\mu_{3}-\mathrm{NH}\right)_{3} \mathrm{Ti}_{3}\left(\eta^{5}-\mathrm{C}_{5} \mathrm{Me}_{5}\right)_{3}\left(\mu_{3}-\mathrm{N}\right)\right\}\right](\mathrm{X}=$ $\mathrm{Cl}(\mathbf{3}), \mathrm{I}(\mathbf{5})$ ) have been reported previously. ${ }^{[22]}$ However, to establish a comparison with the analogous copper(I) bromide (4) and triflate (6) adducts, herein we include the NMR data in $\left[\mathrm{D}_{1}\right]$ chloroform. 3: ${ }^{1} \mathrm{H}$ NMR (300 MHz, $\left.\mathrm{CDCl}_{3}, 20{ }^{\circ} \mathrm{C}, \mathrm{TMS}\right): \delta=11.63$ (s broad, $3 \mathrm{H}$; NH), $2.02 \mathrm{ppm}\left(\mathrm{s}, 45 \mathrm{H} ; \mathrm{C}_{5} \mathrm{Me}_{5}\right) ;{ }^{13} \mathrm{C}\left\{{ }^{1} \mathrm{H}\right\}$ NMR (75 MHz, $\left.\mathrm{CDCl}_{3}, 20{ }^{\circ} \mathrm{C}, \mathrm{TMS}\right): \delta=119.6$ $\left(C_{5} \mathrm{Me}_{5}\right), 11.6 \mathrm{ppm}\left(\mathrm{C}_{5} \mathrm{Me}_{5}\right) .5:{ }^{1} \mathrm{H} \mathrm{NMR}\left(300 \mathrm{MHz}, \mathrm{CDCl}_{3}, 20{ }^{\circ} \mathrm{C}, \mathrm{TMS}\right): \delta=11.61$ (s broad, 3H; NH), $2.02 \mathrm{ppm}\left(\mathrm{s}, 45 \mathrm{H} ; \mathrm{C}_{5} \mathrm{Me}_{5}\right) ;{ }^{13} \mathrm{C}\left\{{ }^{1} \mathrm{H}\right\} \mathrm{NMR}\left(75 \mathrm{MHz}, \mathrm{CDCl}_{3}, 20{ }^{\circ} \mathrm{C}, \mathrm{TMS}\right): \delta=$ $119.7\left(C_{5} \mathrm{Me}_{5}\right), 11.7 \mathrm{ppm}\left(\mathrm{C}_{5} \mathrm{Me}_{5}\right)$.

Synthesis of $\left[\left(\mathrm{CF}_{3} \mathrm{SO}_{2} \mathrm{O}\right) \mathrm{Cu}\left\{\left(\mu_{3}-\mathrm{NH}\right)_{3} \mathrm{Ti}_{3}\left(\eta^{5}-\mathrm{C}_{5} \mathrm{Me}_{5}\right)_{3}\left(\mu_{3}-\mathrm{N}\right)\right\}\right](6)$. A $100 \mathrm{~mL}$ Schlenk flask was charged with $1(0.72 \mathrm{~g}, 1.18 \mathrm{mmol}),\left[\left\{\mathrm{Cu}\left(\mathrm{O}_{3} \mathrm{SCF}_{3}\right)\right\}_{2} \cdot \mathrm{C}_{7} \mathrm{H}_{8}\right](0.30 \mathrm{~g}, 0.58 \mathrm{mmol})$ and dichloromethane $(70 \mathrm{~mL})$. The reaction mixture was stirred at room temperature for $16 \mathrm{~h}$ to give a red solution. After filtration, the volatile components were removed under reduced pressure to give a red solid. This solid was washed with toluene $(5 \mathrm{~mL})$ and vacuum-dried to give $6 \cdot \mathrm{C}_{7} \mathrm{H}_{8}$ as an orange solid $(0.65 \mathrm{~g}, 61 \%) .{ }^{1} \mathrm{H} \mathrm{NMR}\left(300 \mathrm{MHz}, \mathrm{CDCl}_{3}, 20{ }^{\circ} \mathrm{C}, \mathrm{TMS}\right): \delta=$ 11.49 (s broad, 3H; NH), 2.03 ppm (s, 45H; $\left.\mathrm{C}_{5} \mathrm{Me}_{5}\right) ;{ }^{13} \mathrm{C}\left\{{ }^{1} \mathrm{H}\right\} \mathrm{NMR}\left(75 \mathrm{MHz}, \mathrm{CDCl}_{3}, 20{ }^{\circ} \mathrm{C}\right.$, TMS $): \delta=120.2\left(C_{5} \mathrm{Me}_{5}\right), 11.6 \mathrm{ppm}\left(\mathrm{C}_{5} M e_{5}\right)$, the $C_{F_{3}}$ carbon atom resonance was not detected; ${ }^{19} \mathrm{~F}$ NMR $\left(282 \mathrm{MHz}, \mathrm{CDCl}_{3}, 20{ }^{\circ} \mathrm{C}, \mathrm{CFCl}_{3}\right): \delta=-77.9 \mathrm{ppm}\left(\mathrm{CF}_{3}\right) ; \mathrm{IR}(\mathrm{KBr}): \tilde{v}=$ 3308 (s), 2947 (m), 2908 (s), 2858 (m), 1618 (w), 1487 (m), 1452 (m), 1429 (m), 1380 (s), 1272 (vs), 1262 (vs), 1220 (s), 1149 (vs), 1030 (vs), 770 (m), 745 (s), 695 (w), 665 (s), 646 (vs), $637(\mathrm{vs}), 570(\mathrm{w}), 516(\mathrm{~m}), 476(\mathrm{w}), 431(\mathrm{~m}), 403(\mathrm{~m}) \mathrm{cm}^{-1}$; elemental analysis calcd (\%) for $\mathrm{C}_{38} \mathrm{H}_{56} \mathrm{CuF}_{3} \mathrm{~N}_{4} \mathrm{O}_{3} \mathrm{STi}_{3}\left(M_{w}=913.09\right)$ : C 49.99, $\mathrm{H}$ 6.18, N 6.14, S 3.51; found: $\mathrm{C} 49.95, \mathrm{H}$ 6.46, N 6.34, S 3.33. 
Synthesis of $\left[\mathrm{ClCu}\left\{\left(\mu_{3}-\mathbf{N H}\right)_{3} \mathbf{T i}_{3}\left(\eta^{5}-\mathrm{C}_{5} \mathrm{Me}_{5}\right) 3\left(\mu_{4}-\mathrm{N}\right) \mathrm{CuCl}\right\}\right]$ (7). A $100 \mathrm{~mL}$ Schlenk flask was charged with $1(0.30 \mathrm{~g}, 0.49 \mathrm{mmol}), \mathrm{CuCl}(0.10 \mathrm{~g}, 1.01 \mathrm{mmol})$ and toluene $(40 \mathrm{~mL})$. The reaction mixture was stirred at room temperature for $24 \mathrm{~h}$ to give a dark red solution. After filtration, the volatile components were removed under reduced pressure to give a red solid. This solid was washed with hexane $(10 \mathrm{~mL})$ and vacuum-dried to give $7 \cdot \mathrm{C}_{7} \mathrm{H}_{8}$ as a dark red powder $(0.27 \mathrm{~g}, 61 \%) .{ }^{1} \mathrm{H}$ NMR $\left(300 \mathrm{MHz}, \mathrm{CDCl}_{3}, 20{ }^{\circ} \mathrm{C}, \mathrm{TMS}\right): \delta=11.98$ (s broad, $3 \mathrm{H}$; $\mathrm{NH}), 2.15 \mathrm{ppm}\left(\mathrm{s}, 45 \mathrm{H} ; \mathrm{C}_{5} \mathrm{Me}_{5}\right) ;{ }^{13} \mathrm{C}\left\{{ }^{1} \mathrm{H}\right\}$ NMR (75 MHz, $\left.\mathrm{CDCl}_{3}, 20{ }^{\circ} \mathrm{C}, \mathrm{TMS}\right): \delta=123.3$ (C $\left.C_{5} \mathrm{Me}_{5}\right), 12.7$ ppm $\left(\mathrm{C}_{5} M e_{5}\right)$; IR (KBr): $\tilde{v}=3356(\mathrm{~s}), 3224(\mathrm{~m}), 2907(\mathrm{~s}), 2856(\mathrm{~m}), 1604(\mathrm{w})$, 1494 (m), 1427 (s), 1379 (s), 1067 (w), 1025 (m), 927 (w), 792 (m), 732 (m), 696 (m), 645 (s), $610(\mathrm{vs}), 549$ (w), $521(\mathrm{w}), 465$ (w), $434(\mathrm{~s}) \mathrm{cm}^{-1}$; elemental analysis calcd (\%) for $\mathrm{C}_{37} \mathrm{H}_{56} \mathrm{Cl}_{2} \mathrm{Cu}_{2} \mathrm{~N}_{4} \mathrm{Ti}_{3}\left(M_{w}=898.48\right):$ C 49.46, H 6.28, N 6.23; found: C 49.48, H 6.04, N 6.24.

Synthesis of $\left[\mathrm{BrCu}\left\{\left(\mu_{3}-\mathrm{NH}\right)_{3} \mathrm{Ti}_{3}\left(\eta^{5}-\mathrm{C}_{5} \mathrm{Me}_{5}\right)_{3}\left(\mu_{4}-\mathrm{N}\right) \mathrm{CuBr}\right\}\right]$ (8). In a fashion similar to the preparation of 7, the treatment of $1(0.30 \mathrm{~g}, 0.49 \mathrm{mmol})$ with $\mathrm{CuBr}(0.14 \mathrm{~g}, 0.99 \mathrm{mmol})$ in toluene $(50 \mathrm{~mL})$ for 3 days produced 8 as a dark red powder $(0.26 \mathrm{~g}, 59 \%) .{ }^{1} \mathrm{H}$ NMR (300 $\left.\mathrm{MHz}, \mathrm{CDCl}_{3}, 2{ }^{\circ} \mathrm{C}, \mathrm{TMS}\right): \delta=11.98$ (s broad, $\left.3 \mathrm{H} ; \mathrm{NH}\right), 2.16 \mathrm{ppm}\left(\mathrm{s}, 45 \mathrm{H} ; \mathrm{C}_{5} \mathrm{Me}_{5}\right)$; ${ }^{13} \mathrm{C}\left\{{ }^{1} \mathrm{H}\right\} \mathrm{NMR}\left(75 \mathrm{MHz}, \mathrm{CDCl}_{3}, 20{ }^{\circ} \mathrm{C}, \mathrm{TMS}\right): \delta=123.1\left(C_{5} \mathrm{Me}_{5}\right), 12.8 \mathrm{ppm}\left(\mathrm{C}_{5} \mathrm{Me}_{5}\right) ; \mathrm{IR}$ $(\mathrm{KBr}): \tilde{v}=3355(\mathrm{~s}), 2907$ (s), $2856(\mathrm{~m}), 1486(\mathrm{~m}), 1425$ (s), $1379(\mathrm{~s}), 1067(\mathrm{w}), 1023(\mathrm{~m})$, 764 (vs), 700 (s), 666 (s), 611 (vs), 548 (m), 437 (s), 421 (m) cm ${ }^{-1}$; elemental analysis calcd (\%) for $\mathrm{C}_{30} \mathrm{H}_{48} \mathrm{Br}_{2} \mathrm{Cu}_{2} \mathrm{~N}_{4} \mathrm{Ti}_{3}\left(M_{w}=895.24\right)$ : C 40.25, H 5.40, N 6.26; found: C 40.29, H 5.33, N 6.18.

Synthesis of $\left[\operatorname{ICu}\left\{\left(\mu_{3}-\mathrm{NH}\right)_{3} \mathrm{Ti}_{3}\left(\eta^{5}-\mathrm{C}_{5} \mathrm{Me}_{5}\right)_{3}\left(\mu_{4}-\mathrm{N}\right) \mathrm{CuI}\right\}\right]$ (9). In a fashion similar to the preparation of 7, treatment of $1(0.30 \mathrm{~g}, 0.49 \mathrm{mmol})$ with $\mathrm{CuI}(0.19 \mathrm{~g}, 1.00 \mathrm{mmol})$ in toluene (50 mL) for 4 days produced a red solid. Analysis of this solid by ${ }^{1} \mathrm{H}$ NMR spectroscopy in $\left[\mathrm{D}_{1}\right]$ chloroform revealed a 60:40 mixture of complexes $\mathbf{5}$ and $\mathbf{9}$. Crystallization from toluene $(10 \mathrm{~mL})$ at $-25^{\circ} \mathrm{C}$ for 7 days gave X-ray quality red crystals of $9 \cdot 3 \mathrm{C}_{7} \mathrm{H}_{8}(0.095 \mathrm{~g}, 15 \%)$. These 
crystals lose the toluene solvent molecules upon standing at room temperature for a few minutes according to microanalysis data. Furthermore, NMR analysis of the crystals in $\left[\mathrm{D}_{1}\right]$ chloroform does not show resonances for $\mathrm{C}_{7} \mathrm{H}_{8}$ molecules and reveal an 80:20 mixture of compounds 5 and 9. Spectral and analytical data for 9: ${ }^{1} \mathrm{H} \mathrm{NMR}\left(300 \mathrm{MHz}, \mathrm{CDCl}_{3}, 20{ }^{\circ} \mathrm{C}\right.$, TMS): $\delta=11.97$ (s broad, 3H; NH), $2.16 \mathrm{ppm}\left(\mathrm{s}, 45 \mathrm{H} ; \mathrm{C}_{5} \mathrm{Me}_{5}\right) ;{ }^{13} \mathrm{C}\left\{{ }^{1} \mathrm{H}\right\} \mathrm{NMR}(75 \mathrm{MHz}$, $\left.\mathrm{CDCl}_{3}, 20^{\circ} \mathrm{C}, \mathrm{TMS}\right): \delta=123.1\left(C_{5} \mathrm{Me}_{5}\right), 12.9 \mathrm{ppm}\left(\mathrm{C}_{5} M e_{5}\right) ; \mathrm{IR}(\mathrm{KBr}): \tilde{v}=3360(\mathrm{~m}), 3314$ (m), 2907 (s), 2855 (m), 1488 (m), 1426 (m), 1377 (s), 1066 (w), 1022 (m), 763 (s), 706 (m), $663(\mathrm{~m}), 645$ (vs), $610(\mathrm{vs}), 549(\mathrm{w}), 522(\mathrm{w}), 477(\mathrm{w}), 434(\mathrm{~s}), 406(\mathrm{~m}) \mathrm{cm}^{-1}$; elemental analysis calcd (\%) for $\mathrm{C}_{30} \mathrm{H}_{48} \mathrm{Cu}_{2} \mathrm{I}_{2} \mathrm{~N}_{4} \mathrm{Ti}_{3}\left(M_{w}=989.23\right)$ : C 36.42, H 4.89, N 5.66; found: $\mathrm{C}$ 36.78, H 5.13, N 5.41.

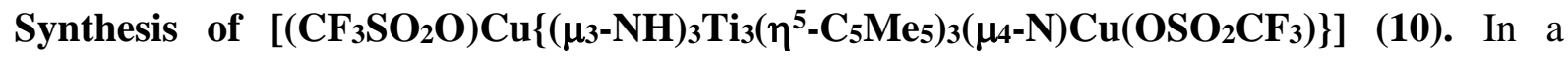
fashion similar to the preparation of 7, treatment of $1(0.30 \mathrm{~g}, 0.49 \mathrm{mmol})$ with $\left[\left\{\mathrm{Cu}\left(\mathrm{O}_{3} \mathrm{SCF}_{3}\right)\right\}_{2} \cdot \mathrm{C}_{7} \mathrm{H}_{8}\right](0.26 \mathrm{~g}, 0.50 \mathrm{mmol})$ in toluene $(30 \mathrm{~mL})$ for 3 days afforded $\mathbf{1 0}$ as an orange powder $(0.33 \mathrm{~g}, 65 \%) .{ }^{1} \mathrm{H}$ NMR $\left(300 \mathrm{MHz}, \mathrm{CDCl}_{3}, 20{ }^{\circ} \mathrm{C}, \mathrm{TMS}\right): \delta=11.95$ (s broad, 3H; NH), 2.17 ppm (s, 45H; $\left.\mathrm{C}_{5} \mathrm{Me}_{5}\right) ;{ }^{13} \mathrm{C}\left\{{ }^{1} \mathrm{H}\right\}$ NMR (75 MHz, $\left.\mathrm{CDCl}_{3}, 20{ }^{\circ} \mathrm{C}, \mathrm{TMS}\right): \delta=$ $124.3\left(C_{5} \mathrm{Me}_{5}\right), 12.6 \mathrm{ppm}\left(\mathrm{C}_{5} M e_{5}\right)$, the $C_{\mathrm{F}_{3}}$ carbon atom resonances were not detected; ${ }^{19} \mathrm{~F}$ $\operatorname{NMR}\left(282 \mathrm{MHz}, \mathrm{CDCl}_{3}, 20^{\circ} \mathrm{C}, \mathrm{CFCl}_{3}\right): \delta=-77.4 \mathrm{ppm}\left(\mathrm{CF}_{3}\right) ; \mathrm{IR}(\mathrm{KBr}): \tilde{v}=3355(\mathrm{~m}), 3304$ (m), 2914 (m), 2861 (w), 1490 (w), 1426 (w), 1382 (m), 1334 (s), 1311 (s), 1236 (s), 1207 (vs), 1204 (vs), 1200 (vs), 1182 (s), 1168 (s), 1017 (s), 763 (m), 700 (w), 664 (w), 635 (s), 608 (s), $572(\mathrm{w}), 515(\mathrm{~m}), 437(\mathrm{w}), 413(\mathrm{w}) \mathrm{cm}^{-1}$; elemental analysis calcd (\%) for $\mathrm{C}_{32} \mathrm{H}_{48} \mathrm{Cu}_{2} \mathrm{~F}_{6} \mathrm{~N}_{4} \mathrm{O}_{6} \mathrm{~S}_{2} \mathrm{Ti}_{3}\left(M_{w}=1033.56\right): \mathrm{C} 37.19, \mathrm{H}$ 4.68, N 5.42, S 6.20; found: C 37.53, H 4.67, N 5.06, S 6.03 .

Synthesis of $\left[\left\{\operatorname{Ti}\left(\eta^{5}-\mathrm{C}_{5} \mathrm{Me}_{5}\right)\right\}_{4}\left(\mu_{3}-\mathrm{N}\right)_{3}\left\{\left(\mu_{4}-\mathrm{N}\right) \mathrm{CuBr}\right\}\right]$ (11). A $100 \mathrm{~mL}$ Schlenk flask was charged with 2 (0.30 g, $0.38 \mathrm{mmol}), \mathrm{CuBr}(0.06 \mathrm{~g}, 0.42 \mathrm{mmol})$ and toluene $(40 \mathrm{~mL})$. The reaction mixture was stirred at room temperature for 5 days to give a brown solution. After 
filtration, the volatile components were removed under reduced pressure to give a brown solid. Crystallization in toluene $(10 \mathrm{~mL})$ at $-25^{\circ} \mathrm{C}$ for 7 days gave $\mathbf{1 1} \cdot \mathrm{C}_{7} \mathrm{H}_{8}$ as brown crystals (0.20 g, 51\%). ${ }^{1} \mathrm{H}$ NMR (300 MHz, $\left.\mathrm{CDCl}_{3}, 20{ }^{\circ} \mathrm{C}, \mathrm{TMS}\right): \delta=2.15$ (s, 45H; $\mathrm{C}_{5} \mathrm{Me}_{5}$ ), 2.03 ppm (s, 15H; $\left.\mathrm{C}_{5} \mathrm{Me}_{5}\right) ;{ }^{13} \mathrm{C}\left\{{ }^{1} \mathrm{H}\right\}$ NMR $\left(75 \mathrm{MHz}, \mathrm{CDCl}_{3}, 20{ }^{\circ} \mathrm{C}, \mathrm{TMS}\right): \delta=122.8,121.4$ (C $\left.C_{5} \mathrm{Me}_{5}\right)$, 13.2, $12.4 \mathrm{ppm}\left(\mathrm{C}_{5} \mathrm{Me}_{5}\right)$; IR (KBr): $\tilde{v}=2906(\mathrm{~s}), 2855(\mathrm{~m}), 1494(\mathrm{w}), 1430(\mathrm{~m})$, 1375 (s), 1065 (w), 1022 (m), 792 (s), 731 (w), $710(\mathrm{w}), 695$ (w), 639 (vs), 615 (vs), 592 (m), $441(\mathrm{~s}) \mathrm{cm}^{-1}$; elemental analysis calcd $(\%)$ for $\mathrm{C}_{47} \mathrm{H}_{68} \mathrm{BrCuN}_{4} \mathrm{Ti}_{4}\left(M_{w}=1024.00\right): \mathrm{C} 55.13, \mathrm{H}$ 6.69, N 5.47; found: C 55.31, H 6.62, N 5.21.

Synthesis of $\left[\left\{\mathrm{Ti}\left(\eta^{5}-\mathrm{C}_{5} \mathrm{Me}_{5}\right)\right\}_{4}\left(\mu_{3}-\mathrm{N}\right)_{2}\left\{\left(\mu_{4}-\mathrm{N}\right) \mathrm{CuCl}_{2}\right]\right.$ (12). In a fashion similar to the preparation of 11, treatment of $2(0.30 \mathrm{~g}, 0.38 \mathrm{mmol})$ with $\mathrm{CuCl}(0.08 \mathrm{~g}, 0.81 \mathrm{mmol})$ in toluene (30 mL) gave 12. $\mathrm{C}_{7} \mathrm{H}_{8}$ as brown crystals $(0.20 \mathrm{~g}, 49 \%) .{ }^{1} \mathrm{H} \mathrm{NMR}\left(300 \mathrm{MHz}, \mathrm{CDCl}_{3}\right.$, $\left.20{ }^{\circ} \mathrm{C}, \mathrm{TMS}\right): \delta=2.27\left(\mathrm{~s}, 30 \mathrm{H} ; \mathrm{C}_{5} \mathrm{Me}_{5}\right), 2.20 \mathrm{ppm}\left(\mathrm{s}, 30 \mathrm{H} ; \mathrm{C}_{5} \mathrm{Me}_{5}\right) ;{ }^{13} \mathrm{C}\left\{{ }^{1} \mathrm{H}\right\} \mathrm{NMR}(75 \mathrm{MHz}$, $\left.\mathrm{CDCl}_{3}, 20{ }^{\circ} \mathrm{C}, \mathrm{TMS}\right): \delta=126.5,125.3\left(C_{5} \mathrm{Me}_{5}\right), 14.2,13.6 \mathrm{ppm}\left(\mathrm{C}_{5} M e_{5}\right) ; \mathrm{IR}(\mathrm{KBr}): \tilde{v}=2906$ (s), 2855 (m), 1602 (w), 1494 (m), 1426 (s), 1378 (s), 1066 (w), 1022 (m), 793 (s), 740 (s), 697 (m), 631 (vs), 611 (vs), 440 (s) cm ${ }^{-1}$; elemental analysis calcd (\%) for $\mathrm{C}_{47} \mathrm{H}_{68} \mathrm{Cl}_{2} \mathrm{Cu}_{2} \mathrm{~N}_{4} \mathrm{Ti}_{4}$ $\left(M_{w}=1078.55\right):$ C 52.34, H 6.35, N 5.20; found: C 52.45, H 6.53, N 5.07.

Synthesis of $\left[\left\{\mathrm{Ti}\left(\eta^{5}-\mathrm{C}_{5} \mathrm{Me}_{5}\right)\right\}_{4}\left(\mu_{3}-\mathrm{N}\right)\left\{\left(\mu_{4}-\mathrm{N}\right) \mathrm{CuOSO}_{2} \mathrm{CF}_{3}\right\}_{3}\right]$ (13). A $100 \mathrm{~mL}$ Schlenk flask was charged with $2(0.20 \mathrm{~g}, 0.25 \mathrm{mmol}),\left[\left\{\mathrm{Cu}\left(\mathrm{O}_{3} \mathrm{SCF}_{3}\right)\right\}_{2} \cdot \mathrm{C}_{7} \mathrm{H}_{8}\right](0.20 \mathrm{~g}, 0.39 \mathrm{mmol})$ and toluene $(30 \mathrm{~mL})$. The reaction mixture was stirred at room temperature for 3 days to give a brown solution. After filtration, the volatile components were removed under reduced pressure to give a brown solid. The solid was washed with hexane $(10 \mathrm{~mL})$ and vacuum-dried to give 13 as a brown powder $(0.27 \mathrm{~g}, 75 \%) .{ }^{1} \mathrm{H}$ NMR $\left(300 \mathrm{MHz}, \mathrm{CDCl}_{3}, 20{ }^{\circ} \mathrm{C}, \mathrm{TMS}\right): \delta=$ 2.39 (s, 15H; $\left.\mathrm{C}_{5} \mathrm{Me}_{5}\right), 2.33 \mathrm{ppm}\left(\mathrm{s}, 45 \mathrm{H} ; \mathrm{C}_{5} \mathrm{Me}_{5}\right) ;{ }^{13} \mathrm{C}\left\{{ }^{1} \mathrm{H}\right\} \mathrm{NMR}\left(75 \mathrm{MHz}, \mathrm{CDCl}_{3}, 20{ }^{\circ} \mathrm{C}\right.$, TMS $): \delta=131.5,130.6\left(C_{5} \mathrm{Me}_{5}\right), 15.1,14.4 \mathrm{ppm}\left(\mathrm{C}_{5} M e_{5}\right)$, the $C_{\mathrm{F}_{3}}$ carbon atom resonance was not detected; ${ }^{19} \mathrm{~F}$ NMR $\left(282 \mathrm{MHz}, \mathrm{CDCl}_{3}, 20{ }^{\circ} \mathrm{C}, \mathrm{CFCl}_{3}\right): \delta=-77.2 \mathrm{ppm}\left(\mathrm{CF}_{3}\right)$; IR 
$(\mathrm{KBr}): \tilde{v}=2912(\mathrm{~m}), 1489(\mathrm{w}), 1427(\mathrm{~m}), 1381$ (m), 1331 (s), 1237 (vs), 1199 (vs), 1179 (vs), 1011 (vs), 780 (s), 736 (m), 634 (vs), 589 (vs), 515 (m), 440 (m) cm cm $^{-1}$ elemental analysis calcd (\%) for $\mathrm{C}_{43} \mathrm{H}_{60} \mathrm{Cu}_{3} \mathrm{~F}_{9} \mathrm{~N}_{4} \mathrm{O}_{9} \mathrm{~S}_{3} \mathrm{Ti}_{4}\left(M_{w}=1426.25\right)$ : C 36.21, H 4.24, N 3.93, S 6.74; found: C 36.64, H 4.41, N 3.70, S 6.65.

Synthesis of $\left[\left\{\mathrm{Ti}\left(\eta^{5}-\mathrm{C}_{5} \mathrm{Me}_{5}\right)\right\}_{4}\left(\mu_{3}-\mathrm{N}\right)_{3}\left\{\left(\mu_{4}-\mathrm{N}\right) \mathbf{A g O S O}_{2} \mathrm{CF}_{3}\right\}\right](14)$. A $100 \mathrm{~mL}$ amber stained Schlenk flask was charged with $2(0.20 \mathrm{~g}, 0.25 \mathrm{mmol}),\left[\mathrm{Ag}\left(\mathrm{O}_{3} \mathrm{SCF}_{3}\right)\right](0.07 \mathrm{~g}, 0.27 \mathrm{mmol})$ and toluene $(60 \mathrm{~mL})$. The reaction mixture was stirred at room temperature for 4 days to give a brown solution. After filtration, the volatile components were removed under reduced pressure to give a brown solid. The solid was washed with hexane $(10 \mathrm{~mL})$ and vacuum-dried to give 14 as a brown powder $(0.15 \mathrm{~g}, 58 \%) .{ }^{1} \mathrm{H} \mathrm{NMR}\left(300 \mathrm{MHz}, \mathrm{CDCl}_{3}, 20{ }^{\circ} \mathrm{C}, \mathrm{TMS}\right): \delta=$ 2.10 (s, 45H; $\left.\mathrm{C}_{5} \mathrm{Me}_{5}\right), 2.03 \mathrm{ppm}\left(\mathrm{s}, 15 \mathrm{H} ; \mathrm{C}_{5} \mathrm{Me}_{5}\right) ;{ }^{13} \mathrm{C}\left\{{ }^{1} \mathrm{H}\right\} \mathrm{NMR}\left(75 \mathrm{MHz}, \mathrm{CDCl}_{3}, 20{ }^{\circ} \mathrm{C}\right.$, TMS $): \delta=122.7,121.9\left(C_{5} \mathrm{Me}_{5}\right), 12.9,12.4 \mathrm{ppm}\left(\mathrm{C}_{5} M e_{5}\right)$, the $C_{\mathrm{F}_{3}}$ carbon atom resonance was not detected; ${ }^{19} \mathrm{~F}$ NMR $\left(282 \mathrm{MHz} \mathrm{CDCl}_{3}, 20{ }^{\circ} \mathrm{C}, \mathrm{CFCl}_{3}\right): \delta=-77.2 \mathrm{ppm}\left(\mathrm{CF}_{3}\right)$; IR $(\mathrm{KBr}): \tilde{v}=2910(\mathrm{~s}), 2858(\mathrm{~m}), 1491(\mathrm{w}), 1436(\mathrm{~m}), 1376(\mathrm{~s}), 1324(\mathrm{~s}), 1251(\mathrm{~m}), 1232(\mathrm{~s})$, 1200 (vs), 1166 (s), 1030 (m), 1014 (vs), 791 (vs), 716 (w), 650 (vs), 631 (vs), 619 (vs), 592 (m), $515(\mathrm{w}), 440(\mathrm{~s}) \mathrm{cm}^{-1}$; elemental analysis calcd $(\%)$ for $\mathrm{C}_{41} \mathrm{H}_{60} \mathrm{AgF}_{3} \mathrm{~N}_{4} \mathrm{O}_{3} \mathrm{STi}_{4}\left(M_{w}=\right.$ 1045.35): C 47.11, H 5.78, N 5.36, S 3.07; found: C 46.89, H 5.65, N 5.08, S 2.86.

X-ray structure determination of complexes 8-13. Suitable red $\left(8 \cdot \mathrm{C}_{7} \mathrm{H}_{8}, 9 \cdot 3 \mathrm{C}_{7} \mathrm{H}_{8}, 10\right)$ or brown $\left(\mathbf{1 1} \cdot \mathrm{C}_{7} \mathrm{H}_{8}, \mathbf{1 2} \cdot \mathrm{C}_{7} \mathrm{H}_{8}, \mathbf{1 3} \cdot 2 \mathrm{C}_{7} \mathrm{H}_{8}\right)$ crystals were obtained from toluene solutions at $-20{ }^{\circ} \mathrm{C}$ or $-25^{\circ} \mathrm{C}$. Crystals were removed from the Schlenks and covered with a layer of a viscous perfluoropolyether (Fomblin $\left.{ }^{\circledR} \mathrm{Y}\right)$. A suitable crystal was selected with the aid of a microscope, attached to a glass fiber, and immediately placed in the low temperature nitrogen stream of the diffractometer. The intensity data sets were collected at $200 \mathrm{~K}$ on a Bruker-Nonius KappaCCD diffractometer equipped with an Oxford Cryostream 700 unit. Crystallographic data for all the complexes are presented in Table 5 (see page 36). 
The structures were solved, using the WINGX package, ${ }^{[29]}$ by direct methods (SHELXS-97) ${ }^{[30]}$ and refined by least-squares against $\mathrm{F}^{2}$ (SHELXL-97). ${ }^{[30]}$ All non-hydrogen atoms were anisotropically refined, except for the carbon atoms of one disordered pentamethylcyclopentadienyl moiety in $\mathbf{1 1} \cdot \mathrm{C}_{7} \mathrm{H}_{8}$. Hydrogen atoms were geometrically placed and left riding on their parent atoms. Except for compounds $12 \cdot \mathrm{C}_{7} \mathrm{H}_{8}$ and $\mathbf{1 3} \cdot 2 \mathrm{C}_{7} \mathrm{H}_{8}$, SIMU and DELU restraints were applied.

In 8. $\mathrm{C}_{7} \mathrm{H}_{8}$ one pentamethylcyclopentadienyl group was disordered in two positions. For 10 one of the trifluromethanesulfonate groups showed some disorder that was partially treated. In 11. $\mathrm{C}_{7} \mathrm{H}_{8}$ one pentamethylcyclopentadienyl unit was disordered in two positions and the carbon atoms were left isotropic. For $\mathbf{1 1} \cdot \mathrm{C}_{7} \mathrm{H}_{8}$ and $\mathbf{1 2} \cdot \mathrm{C}_{7} \mathrm{H}_{8}$, two chemically equivalent molecules of the compound appeared in the asymmetric unit. As well, one molecule of toluene crystallized with every molecule of the compound, these solvent molecules were found in the difference Fourier map but were very disordered and it was not possible to get a chemical sensible model for them, so Squeeze procedure ${ }^{[31]}$ was used to remove their contribution to the structure factors. Finally in $13 \cdot 2 \mathrm{C}_{7} \mathrm{H}_{8}$ some disorder was observer in two of the trifluromethanesulfonate moieties and was partially treated.

CCDC-735152 (8), 735153 (9), 735154 (10), 735155 (11), 735156 (12), and 735157 (13) contain the supplementary crystallographic data for this paper. These data can be obtained free of charge from The Cambridge Crystallographic Data Centre via www.ccdc.cam.ac.uk/data_request/cif.

Computational Details. All calculations were performed by using the density functionalbased ADF2005.01 package. ${ }^{[32]}$ Full DFT calculations were carried out on model complexes, in which the pentamethylcyclopentadienyl ligands were replaced by cyclopentadienyl. Equilibrium structures and associated energies were obtained at the BP86 level within the framework of the generalized gradient approximation (GGA), applying the X $\alpha$ model with 
Becke's corrections ${ }^{[33]}$ for describing exchange, and the VWN parameterization ${ }^{[34]}$ with Perdew's corrections ${ }^{[35]}$ for correlation. To describe the valence electrons we used a SlaterTZP-quality basis set. The core electrons (C, N, O: 1s; S, Cl: 1s-2p; Br: 1s-3d; I: 1s-4d; Ti, $\mathrm{Cu}: 1 \mathrm{~s}-3 \mathrm{p} ; \mathrm{Ag}: 1 \mathrm{~s}-4 \mathrm{p})$ were kept frozen and described by single Slater functions. We applied scalar relativistic corrections to them via the zeroth-order regular approximation (ZORA) with the core potentials generated using the DIRAC program. ${ }^{[36]}$ For adducts formed from complex $\left[\left\{\mathrm{Ti}\left(\eta^{5}-\mathrm{C}_{5} \mathrm{H}_{5}\right)(\mu-\mathrm{NH})\right\}_{3}\left(\mu_{3}-\mathrm{N}\right)\right]\left(\mathbf{1}^{\prime}\right)$ and metal halides, we optimized the structures using $C_{3 v}$ symmetry restriction. We also checked the effect of lowering the symmetry on the geometry and energy (see text for details). In the case of the adducts formed from $\left[\left\{\operatorname{Ti}\left(\eta^{5}-\mathrm{C}_{5} \mathrm{H}_{5}\right)\right\}_{4}\left(\mu_{3^{-}}\right.\right.$ $\mathrm{N})_{4}$ ] (2'), the $\mathrm{C}_{\mathrm{s}}$ symmetry restriction was imposed in geometry optimization for adducts with metal halides, whereas for adducts with metal triflates no symmetry restrictions were used. Supporting Information contains Cartesian coordinates and absolute total energies for the computed structures.

To account for the steric effects of the methyl substituents of the $\eta^{5}-\mathrm{C}_{5} \mathrm{Me}_{5}$ ligands, we performed additional hybrid quantum mechanics / molecular mechanics (QMM/MM) calculations $^{[37]}$ as implemented in ADF. ${ }^{[32 f]}$ The QM region of the complexes was $\left[\left\{\mathrm{Ti}\left(\eta^{5}-\right.\right.\right.$ $\left.\left.\left.\mathrm{C}_{5} \mathrm{H}_{5}\right)(\mu-\mathrm{NH})\right\}_{3}\left(\mu_{3}-\mathrm{N}\right)\right],\left[\left\{\mathrm{Ti}\left(\eta^{5}-\mathrm{C}_{5} \mathrm{H}_{5}\right)\right\}_{4}\left(\mu_{3}-\mathrm{N}\right)_{4}\right]$, and the MX fragments, while the MM region was that constituted by the methyl substituents of the $\eta^{5}-\mathrm{C}_{5} \mathrm{Me}_{5}$ groups. The QM level was the same as described above. Molecular Mechanics calculations used the SYBYL force field. ${ }^{[38]}$ The van der Waals parameters for the titanium and copper atoms were taken from the UFF force field, ${ }^{[39]}$ and torsional contributions involving dihedral angles with the metal atom in terminal positions were set to zero. The ratio between the $\mathrm{C}\left(\right.$ aromatic)- $\mathrm{C}\left(\mathrm{sp}^{3}\right)$ bond distance and $\mathrm{C}$ (aromatic)-H bond distance was 1.407. 
Acknowledgements. This work was supported by the Spanish MEC (CTQ2008-00061/BQU and CTQ2008-06549-C02-01/BQU), Comunidad de Madrid and the Universidad de Alcalá (CCG06-UAH/PPQ-0665), DURSI of Generalitat de Catalunya (2005SGR-00104), and Factoría de Cristalización (CONSOLIDER-INGENIO 2010 CSD2006-00015). N. M.-E. thanks the MEC for a doctoral fellowship. 
Table 5. Experimental data for the $\mathrm{X}$-ray diffraction studies on 8-13.

\begin{tabular}{|c|c|c|c|c|c|c|}
\hline & 8. $\mathrm{C}_{7} \mathrm{H}_{8}$ & 9. $3 \mathrm{C}_{7} \mathrm{H}_{8}$ & 10 & 11. $\mathrm{C}_{7} \mathrm{H}_{8}$ & 12. $\mathrm{C}_{7} \mathrm{H}_{8}$ & 13. $2 \mathrm{C}_{7} \mathrm{H}_{8}$ \\
\hline formula & $\mathrm{C}_{37} \mathrm{H}_{56} \mathrm{Br}_{2} \mathrm{Cu}_{2} \mathrm{~N}_{4} \mathrm{Ti}_{3}$ & $\mathrm{C}_{51} \mathrm{H}_{72} \mathrm{Cu}_{2} \mathrm{I}_{2} \mathrm{~N}_{4} \mathrm{Ti}_{3}$ & $\mathrm{C}_{32} \mathrm{H}_{48} \mathrm{Cu}_{2} \mathrm{~F}_{6} \mathrm{~N}_{4} \mathrm{O}_{6} \mathrm{~S}_{2} \mathrm{Ti}_{3}$ & $\mathrm{C}_{47} \mathrm{H}_{68} \mathrm{BrCuN}_{4} \mathrm{Ti}_{4}$ & $\mathrm{C}_{47} \mathrm{H}_{68} \mathrm{Cl}_{2} \mathrm{Cu}_{2} \mathrm{~N}_{4} \mathrm{Ti}_{4}$ & $\mathrm{C}_{57} \mathrm{H}_{76} \mathrm{Cu}_{3} \mathrm{~F}_{9} \mathrm{~N}_{4} \mathrm{O}_{9} \mathrm{~S}_{3} \mathrm{Ti}_{4}$ \\
\hline$M_{\mathrm{r}}$ & 987.46 & 1265.71 & 1033.64 & 1024.10 & 1078.63 & 1610.62 \\
\hline$T[\mathrm{~K}]$ & $200(2)$ & $200(2)$ & $200(2)$ & $200(2)$ & $200(2)$ & $200(2)$ \\
\hline$\lambda[\AA]$ & 0.71073 & 0.71073 & 0.71073 & 0.71073 & 0.71073 & 0.71073 \\
\hline crystal system & triclinic & triclinic & monoclinic & monoclinic & monoclinic & monoclinic \\
\hline space group & $P-1$ & $P-1$ & $P 2_{l} / c$ & $P 2_{l} / \mathrm{c}$ & $P 2_{1} / c$ & $P 2_{1} / c$ \\
\hline$a[\AA]$ & $11.734(2)$ & $12.143(3)$ & $11.310(2)$ & $23.786(9)$ & $21.393(5)$ & $12.065(3)$ \\
\hline$b[\AA]$ & $12.342(4)$ & $14.377(2)$ & $19.545(4)$ & $21.132(11)$ & $15.004(6)$ & $21.989(3)$ \\
\hline$c[\AA]$ & $15.103(4)$ & $17.140(3)$ & $19.402(2)$ & $22.103(7)$ & $39.138(11)$ & $26.689(6)$ \\
\hline$\alpha\left[^{\circ}\right]$ & $78.26(2)$ & $71.98(2)$ & & & & \\
\hline$\beta\left[^{\circ}\right]$ & $83.47(2)$ & $79.19(2)$ & $96.38(1)$ & $116.89(2)$ & $92.09(2)$ & $102.83(2)$ \\
\hline$\gamma\left[^{\circ}\right]$ & $82.16(2)$ & $82.08(2)$ & & & & \\
\hline$V\left[\AA^{3}\right]$ & $2113.2(8)$ & $2784.9(9)$ & $4262.4(11)$ & $9908(7)$ & $12554(6)$ & $6904(2)$ \\
\hline $\mathrm{Z}$ & 2 & 2 & 4 & 8 & 8 & 4 \\
\hline$\rho_{\text {calcd }}\left[\mathrm{g} \mathrm{cm}^{-3}\right]$ & 1.552 & 1.509 & 1.611 & 1.373 & 1.141 & 1.550 \\
\hline$\mu_{\mathrm{MoK} \alpha}\left[\mathrm{mm}^{-1}\right]$ & 3.452 & 2.306 & 1.688 & 1.880 & 1.263 & 1.513 \\
\hline$F(000)$ & 1000 & 1272 & 2104 & 4240 & 4464 & 3288 \\
\hline crystal size $[\mathrm{mm}]$ & $0.35 \times 0.29 \times 0.12$ & $0.48 \times 0.46 \times 0.30$ & $0.44 \times 0.31 \times 0.17$ & $0.50 \times 0.30 \times 0.10$ & $0.45 \times 0.36 \times 0.33$ & $0.46 \times 0.35 \times 0.27$ \\
\hline$\theta$ range $\left[{ }^{\circ}\right]$ & 3.14 to 27.50 & 3.27 to 27.50 & 3.03 to 25.00 & 3.04 to 27.51 & 3.01 to 27.51 & 3.13 to 27.53 \\
\hline index ranges & $-15<=h<=14$, & $-15<=h<=15$, & $-13<=h<=13$, & $-30<=h<=30$, & $-27<=h<=27$, & $-15<=h<=15$, \\
\hline & $-16<=k<=16$ & $-18<=k<=18$, & $-23<=k<=23$, & $-27<=k<=27$, & $-19<=k<=19$, & $-27<=k<=28$, \\
\hline & $-19<=l<=19$ & $-22<=l<=22$ & $-23<=l<=23$ & $-28<=l<=28$ & $-50<=l<=50$ & $-34<=l<=34$ \\
\hline reflns collected & 18168 & 50294 & 77725 & 170014 & 177400 & 123604 \\
\hline unique data & $9539\left[\mathrm{R}_{\mathrm{int}}=0.0823\right]$ & $12498\left[\mathrm{R}_{\mathrm{int}}=0.0429\right]$ & $7468\left[\mathrm{R}_{\mathrm{int}}=0.1221\right]$ & $22435\left[\mathrm{R}_{\mathrm{int}}=0.1369\right]$ & $28124\left[\mathrm{R}_{\mathrm{int}}=0.2028\right]$ & $15833\left[\mathrm{R}_{\mathrm{int}}=0.0874\right]$ \\
\hline obsd data $[\mathrm{I}>2 \sigma(\mathrm{I})]$ & 4873 & 7781 & 4776 & 11778 & 12144 & 9379 \\
\hline GOF on $\mathrm{F}^{2}$ & 0.918 & 1.029 & 1.130 & 1.035 & 0.960 & 1.031 \\
\hline final $\mathrm{R}$ indices & $\mathrm{R} 1=0.0466$ & $\mathrm{R} 1=0.0573$ & $\mathrm{R} 1=0.0743$ & $\mathrm{R} 1=0.0805$ & $\mathrm{R} 1=0.0876$ & $\mathrm{R} 1=0.0660$ \\
\hline$[\mathrm{I}>2 \sigma(\mathrm{I})]$ & $\mathrm{wR} 2=0.0955$ & $\mathrm{wR} 2=0.1364$ & $w R 2=0.1692$ & $\mathrm{wR} 2=0.1933$ & $\mathrm{wR} 2=0.2046$ & $\mathrm{wR} 2=0.1501$ \\
\hline $\mathrm{R}$ indices & $\mathrm{R} 1=0.1410$ & $\mathrm{R} 1=0.1101$ & $\mathrm{R} 1=0.1293$ & $\mathrm{R} 1=0.1566$ & $\mathrm{R} 1=0.1669$ & $\mathrm{R} 1=0.1255$ \\
\hline (all data) & $\mathrm{wR} 2=0.1167$ & $\mathrm{wR} 2=0.1686$ & $w R 2=0.2098$ & $\mathrm{wR} 2=0.2284$ & $\mathrm{wR} 2=0.2434$ & $\mathrm{wR} 2=0.1843$ \\
\hline $\begin{array}{l}\text { largest diff. } \\
\text { Peak/hole }\left(\mathrm{e} \cdot \AA^{-3}\right)\end{array}$ & $0.890 /-0.753$ & $0.983 /-1.509$ & $0.929 /-1.399$ & $1.253 /-1.343$ & $0.734 /-0.789$ & $0.745 /-0.860$ \\
\hline
\end{tabular}

[a] $R 1=\Sigma|| \mathrm{F}_{0}|-| \mathrm{F}_{\mathrm{c}} \mid /\left[\Sigma\left|\mathrm{F}_{0}\right|\right] ; w R 2=\left\{\left[\Sigma w\left(F_{0}^{2}-F_{c}^{2}\right)^{2}\right] /\left[\Sigma w\left(F_{0}^{2}\right)^{2}\right]\right\}^{1 / 2}$. 


\section{References}

[1] W. A. Nugent, J. M. Mayer, Metal-Ligand Multiple Bonds, Wiley, New York, 1988.

[2] a) K. Dehnicke, J. Strähle, Angew. Chem. 1981, 93, 451-464; Angew. Chem. Int. Ed. Engl. 1981, 20, 413-426; b) K. Dehnicke, J. Strähle, Angew. Chem. 1992, 104, 978-1000; Angew. Chem. Int. Ed. Engl. 1992, 31, 955-978. c) K. Dehnicke, F. Weller, J. Strähle, Chem. Soc. Rev. 2001, 30, 125-135.

[3] R. A. Eikey, M. M. Abu-Omar, Coord. Chem. Rev. 2003, 243, 83-124.

[4] See, for example: a) P. A. Shapley, Z.-Y. Own, J. C. Huffmann, Organometallics 1986, 5, 1269-1271; b) R. W. Marshman, P. A. Shapley, J. Am. Chem. Soc. 1990, 112, 8369-8378; c) C. M. Lutz, S. R. Wilson, P. A. Shapley, Organometallics 2005, 24, 3350-3353.

[5] See, for example: a) S. N. Brown, J. Am. Chem. Soc. 1999, 121, 9752-9753; b) T. J. Crevier, B. K. Bennett, J. D. Soper, J. A. Bowman, A. Dehestani, D. A. Hrovat, S. Lovell, W. Kaminsky, J. M. Mayer, J. Am. Chem. Soc. 2001, 123, 1059-1071; c) A. G. Maestri, K. S. Cherry, J. J. Toboni, S. N. Brown, J. Am. Chem. Soc. 2001, 123, 7459-7460; d) S. B. Seymore, S. N. Brown, Inorg. Chem. 2002, 41, 462-469; e) B. K. Bennett, E. Saganic, S. Lovell, W. Kaminsky, A. Samuel, J. M. Mayer, Inorg. Chem. 2003, 42, 4127-4134.

[6] See, for example, a) J. Chatt, B. T. Heaton, J. Chem. Soc. A 1971, 705-707; b) R. Dantona, E. Schweda, J. Strähle, Z. Naturforsch. 1984, B39, 733-735; c) S. Ritter, R. Hübener, U. Abram, J. Chem. Soc., Chem. Commun. 1995, 2047-2048; d) U. Abram, E. Schulz Lang, S. Abram, J. Wegmann, J. R. Dilworth, R. Kirmse, J. D. Woollins, J. Chem. Soc., Dalton Trans. 1997, 623-630; e) L. H. Doerrer, A. J. Graham, M. L. H. Green, J. Chem. Soc., Dalton Trans. 1998, 3941-3946; f) U. Abram, B. Schmidt-Brücken, A. Hagenbach, M. Hecht, R. Kirmse, A. Voigt, Z. Anorg. Allg. Chem. 2003, 629, 838-852. 
[7] E. L. Sceats, J. S. Figueroa, C. C. Cummins, N. M. Loening, P. Van der Wel, R. G. Griffin, Polyhedron 2004, 23, 2751-2768.

[8] a) J. Strähle, Z. Anorg. Allg. Chem. 2003, 629, 828-837, and references therein; b) S. Schwarz, E. Niquet, A. Santos Saez, M. Cots Pascual, J. Strähle, Z. Anorg. Allg. Chem. 2003, 629, 2479-2484; c) D. Morrogh, M. Galceran Mestres, E. Niquet, C. F. Barboza da Silva, A. Santos Saez, S. Schwarz, J. Strähle, Z. Anorg. Allg. Chem. 2005, 631, 1113-1118; d) D. Morrogh, S. Schwarz, C. Maichle-Mössmer, J. Strähle, Z. Anorg. Allg. Chem. 2006, 632, 801806.

[9] a) A. J. Mountford, S. J. Lancaster, S. J. Coles, Acta Crystallogr. 2007, C63, m401-m40; b) A.-M. Fuller, W. Clegg, R. W. Harrington, D. L. Hughes, S. J. Lancaster, Chem. Commun. 2008, 5776-5778.

[10] A. Abarca, M. V. Galakhov, J. Gracia, A. Martín, M. Mena, J.-M. Poblet, J. P. Sarasa, C. Yélamos, Chem. Eur. J. 2003, 9, 2337-2346, and references therein.

[11] a) S. T. Oyama (Ed.), The Chemistry of Transition Metal Carbides and Nitrides, Blakie Academic \& Professional, London, 1996; b) M. M. Banaszak Holl, P. T. Wolczanski, G. D. Van Duyne, J. Am. Chem. Soc. 1990, 112, 7989-7994; c) M. M. Banaszak Holl, P. T. Wolczanski, D. Proserpio, A. Bielecki, D. B. Zax, Chem. Mater. 1996, 8, 2468-2480.

[12] a) S. C. Lee, R. H. Holm, Proc. Natl. Acad. Sci. U.S.A. 2003, 100, 3595-3600; b) S. C. Lee, R. H. Holm, Chem. Rev. 2004, 104, 1135-1157.

[13] a) N. Kuganathan, J. C. Green, H.-J. Himmel, New J. Chem. 2006, 30, 1253-1262; b) H.-J. Himmel, M. Reiher, Angew. Chem. 2006, 118, 6412-6437; Angew. Chem. Int. Ed. 2006, 45, 6264-6288.

[14] a) S. Gambarotta, J. Scott, Angew. Chem. 2004, 116, 5412-5422; Angew. Chem. Int. Ed. 2004, 43, 5298-5308; b) L. P. Spencer, B. A. MacKay, B. O. Patrick, M. D. Fryzuk, Proc. Natl. 
Acad. Sci. U.S.A. 2006, 103, 17094-17098; c) M. D. Fryzuk, Acc. Chem. Res. 2009, 42, $127-$ 133.

[15] a) R. A. Wheeler, R. Hoffmann, J. Strähle, J. Am. Chem. Soc. 1986, 108, 5381-5387; b) K. A. Lawler, R. Hoffmann, M. M. Banaszak Holl, P. T. Wolczanski, Z. Anorg. Allg. Chem. 1996, 622, 392-400; c) J. P. Sarasa, J.-M. Poblet, M. Bénard, Organometallics 2000, 19, 2264-2272.

[16] P. Gómez-Sal, A. Martín, M. Mena, C. Yélamos, J. Chem. Soc., Chem. Commun. 1995, 39, 2185-2186.

[17] A. Abarca, P. Gómez-Sal, A. Martín, M. Mena, J.-M. Poblet, C. Yélamos, Inorg. Chem. 2000, $39,642-651$.

[18] H. W. Roesky, Y. Bai, M. Noltemeyer, Angew. Chem. 1989, 101, 788-789; Angew. Chem. Int. Ed. Engl. 1989, 28, 754-755.

[19] a) A. Abarca, M. Galakhov, P. Gómez-Sal, A. Martín, M. Mena, J.-M. Poblet, C. Santamaría, J. P. Sarasa, Angew. Chem. 2000, 112, 544-547; Angew. Chem. Int. Ed. 2000, 39, 534-537; b) K. Freitag, J. Gracia, A. Martín, M. Mena, J.-M. Poblet, J. P. Sarasa, C. Yélamos, Chem. Eur. J. 2001, 7, 3644-3651; c) M. García-Castro, J. Gracia, A. Martín, M. Mena, J.-M. Poblet, J. P. Sarasa, C. Yélamos, Chem. Eur. J. 2005, 11, 1030-1041.

[20] a) A. Abarca, A. Martín, M. Mena, C. Yélamos, Angew. Chem. 2000, 112, 3602-3605; Angew. Chem. Int. Ed. 2000, 39, 3460-3463; b) M. García-Castro, A. Martín, M. Mena, A. Pérez-Redondo, C. Yélamos, Chem. Eur. J. 2001, 7, 647-651; c) A. Martín, M. Mena, A. Pérez-Redondo, C. Yélamos, Inorg. Chem. 2004, 43, 2491-2498; d) M. García-Castro, A. Martín, M. Mena, C. Yélamos, Organometallics 2007, 26, 408-416.

[21] J. J. Carbó, A. Martín, M. Mena, A. Pérez-Redondo, J.-M. Poblet, C. Yélamos, Angew. Chem. 2007, 119, 3155-3158; Angew. Chem. Int. Ed. 2007, 46, 3095-3098.

[22] A. Martín, N. Martínez-Espada, M. Mena, A. Pérez-Redondo, C. Yélamos, Inorg. Chem. 2006, 45, 6901-6911. 
[23] a) G. A. Lawrance, Chem. Rev. 1986, 86, 17-33; b) D. H. Johnston, D. F. Shriver, Inorg. Chem. 1993, 32, 1045-1047; c) W. Huang, R. Frech, R. A. Wheeler, J. Phys. Chem. 1994, 98, 100-110.

[24] A. Martín, N. Martínez-Espada, M. Mena, M. E. G. Mosquera, A. Pérez-Redondo, C. Yélamos, Chem. Commun. 2008, 6561-6563.

[25] P. G. Eller, D. C. Bradley, M. B. Hursthouse, D. W. Meek, Coord. Chem. Rev. 1977, 24, 195.

[26] a) P. C. Healy, J. D. Kildea, A. H. White, Aust. J. Chem. 1989, 42, 137-148; b) G. N. Richardson, H. Vahrenkamp, J. Organomet. Chem. 2000, 593-594, 44-48; c) V. Comte, H. Vahrenkamp, J. Organomet. Chem. 2001, 627, 153-158; d) E. Yang, R.-Q. Zhuang, Y.-E. Chen, Acta Crystallogr. 2006, E62, m2901-m2903; e) J. M. Goodwin, P.-C. Chiang, M. Brynda, K. Penkina, M. M. Olmstead, T. E. Patten, Dalton Trans. 2007, 3086-3092.

[27] NMR data for $\left[\left\{\mathrm{Ti}\left(\eta^{5}-\mathrm{C}_{5} \mathrm{Me}_{5}\right)\right\}_{4}\left(\mu_{3}-\mathrm{N}\right)_{3}\left\{\left(\mu_{4}-\mathrm{N}\right) \mathrm{CuCl}\right\}\right]:{ }^{1} \mathrm{H} \mathrm{NMR}\left(300 \mathrm{MHz}, \mathrm{CDCl}_{3}, 20{ }^{\circ} \mathrm{C}\right.$, TMS $): \delta=2.13\left(\mathrm{~s}, 45 \mathrm{H} ; \mathrm{C}_{5} \mathrm{Me}_{5}\right), 2.03 \mathrm{ppm}\left(\mathrm{s}, 15 \mathrm{H} ; \mathrm{C}_{5} \mathrm{Me}_{5}\right) ;{ }^{13} \mathrm{C}\left\{{ }^{1} \mathrm{H}\right\} \mathrm{NMR}(75 \mathrm{MHz}$, $\left.\mathrm{CDCl}_{3}, 20^{\circ} \mathrm{C}, \mathrm{TMS}\right): \delta=122.7,121.4\left(C_{5} \mathrm{Me}_{5}\right), 13.0,12.4 \mathrm{ppm}\left(\mathrm{C}_{5} M e_{5}\right) . \mathrm{NMR}$ data for $\left[\left\{\mathrm{Ti}\left(\eta^{5}-\mathrm{C}_{5} \mathrm{Me}_{5}\right)\right\}_{4}\left(\mu_{3}-\mathrm{N}\right)_{3}\left\{\left(\mu_{4}-\mathrm{N}\right) \mathrm{CuI}\right\}\right]:{ }^{1} \mathrm{H} \mathrm{NMR}\left(300 \mathrm{MHz}, \mathrm{CDCl}_{3}, 20{ }^{\circ} \mathrm{C}, \mathrm{TMS}\right): \delta=2.16$ (s, 45H; $\left.\mathrm{C}_{5} \mathrm{Me}_{5}\right), 2.03 \mathrm{ppm}\left(\mathrm{s}, 15 \mathrm{H} ; \mathrm{C}_{5} \mathrm{Me}_{5}\right) ;{ }^{13} \mathrm{C}\left\{{ }^{1} \mathrm{H}\right\} \mathrm{NMR}\left(75 \mathrm{MHz}, \mathrm{CDCl}_{3}, 20{ }^{\circ} \mathrm{C}, \mathrm{TMS}\right)$ : $\delta=122.9,121.4\left(C_{5} \mathrm{Me}_{5}\right), 13.5,12.5 \mathrm{ppm}\left(\mathrm{C}_{5} M e_{5}\right)$. NMR data for $\left[\left\{\mathrm{Ti}\left(\eta^{5}-\mathrm{C}_{5} \mathrm{Me}_{5}\right)\right\}_{4}\left(\mu_{3^{-}}\right.\right.$ $\left.\mathrm{N})_{3}\left\{\left(\mu_{4}-\mathrm{N}\right) \mathrm{CuOSO}_{2} \mathrm{CF}_{3}\right\}\right]:{ }^{1} \mathrm{H}$ NMR $\left(300 \mathrm{MHz}, \mathrm{CDCl}_{3}, 20{ }^{\circ} \mathrm{C}, \mathrm{TMS}\right): \delta=2.11(\mathrm{~s}, 45 \mathrm{H}$; $\left.\mathrm{C}_{5} \mathrm{Me}_{5}\right), 2.03 \mathrm{ppm}\left(\mathrm{s}, 15 \mathrm{H} ; \mathrm{C}_{5} \mathrm{Me}_{5}\right) ;{ }^{13} \mathrm{C}\left\{{ }^{1} \mathrm{H}\right\} \mathrm{NMR}\left(75 \mathrm{MHz}, \mathrm{CDCl}_{3}, 20{ }^{\circ} \mathrm{C}, \mathrm{TMS}\right): \delta=$ 123.1, $121.8\left(C_{5} \mathrm{Me}_{5}\right), 12.9,12.4 \mathrm{ppm}\left(\mathrm{C}_{5} M e_{5}\right)$, the $C_{F_{3}}$ carbon atom resonance was not detected; ${ }^{19} \mathrm{~F}$ NMR $\left(282 \mathrm{MHz}, \mathrm{CDCl}_{3}, 20{ }^{\circ} \mathrm{C}, \mathrm{CFCl}_{3}\right): \delta=-77.4 \mathrm{ppm}\left(\mathrm{CF}_{3}\right)$. NMR data for $\left[\left\{\mathrm{Ti}\left(\eta^{5}-\mathrm{C}_{5} \mathrm{Me}_{5}\right)\right\}_{4}\left(\mu_{3}-\mathrm{N}\right)_{2}\left\{\left(\mu_{4}-\mathrm{N}\right) \mathrm{CuOSO}_{2} \mathrm{CF}_{3}\right\}_{2}\right]:{ }^{1} \mathrm{H} \mathrm{NMR}\left(300 \mathrm{MHz}, \mathrm{CDCl}_{3}, 20{ }^{\circ} \mathrm{C}, \mathrm{TMS}\right):$ $\delta=2.24\left(\mathrm{~s}, 30 \mathrm{H} ; \mathrm{C}_{5} \mathrm{Me}_{5}\right), 2.18 \mathrm{ppm}\left(\mathrm{s}, 30 \mathrm{H} ; \mathrm{C}_{5} \mathrm{Me}_{5}\right) ;{ }^{13} \mathrm{C}\left\{{ }^{1} \mathrm{H}\right\} \mathrm{NMR}\left(75 \mathrm{MHz}, \mathrm{CDCl}_{3}, 20{ }^{\circ} \mathrm{C}\right.$, 
TMS): $\delta=127.3,126.2\left(C_{5} \mathrm{Me}_{5}\right), 13.9,13.4 \mathrm{ppm}\left(\mathrm{C}_{5} M e_{5}\right)$, the $C \mathrm{~F}_{3}$ carbon atom resonance was not detected; ${ }^{19} \mathrm{~F}$ NMR $\left(282 \mathrm{MHz}, \mathrm{CDCl}_{3}, 20{ }^{\circ} \mathrm{C}, \mathrm{CFCl}_{3}\right): \delta=-77.3 \mathrm{ppm}\left(\mathrm{CF}_{3}\right)$.

[28] A. Martín, N. Martínez-Espada, M. Mena, C. Yélamos, Chem. Commun. 2007, 2983-2985.

[29] L. J. Farrugia, J. Appl. Crystallogr. 1999, 32, 837-838.

[30] G. M. Sheldrick, Acta Crystallogr. 2008, A64, 112-122.

[31] P. v. d. Sluis, A. L. Spek, Acta Crystallogr. 1990, A46, 194-201.

[32] a) ADF 2005.01. Department of Theoretical Chemistry, Vrije Universiteit, Amsterdam; b) E. J. Baerends, D. E. Ellis, P. Ros, Chem. Phys. 1973, 2, 41-51; c) L. Versluis, T. Ziegler, J. Chem. Phys. 1988, 88, 322-328; d) G. Te Velde, E. J. Baerends, J. Comp. Phys. 1992, 99, 8498; e) C. Fonseca-Guerra, J. G. Snijders, G. Te Velde, E. J. Baerens, Theor. Chem. Acc. 1998, 99, 391-403; f) T. K. Woo, L. Cavallo, T. Ziegler, Theor. Chem. Acta 1998, 100, 307-313.

[33] a) A. D. Becke, J. Chem. Phys. 1986, 84, 4524-4529; b) A. D. Becke, Phys. Rev. A 1988, 38 , 3098-3100.

[34] S. H. Vosko, L. Wilk, M. Nusair, Can. J. Phys. 1980, 58, 1200-1211.

[35] a) J. P. Perdew, Phys. Rev. B 1986, 33, 8822-8824; b) J. P. Perdew, Phys. Rev. B 1986, 33, 7406-7406.

[36] a) J. G. Snijders, E. J. Baerends, Mol. Phys. 1978, 36, 1789-1804; b) J. G. Snijders, E. J. Baerends, P. Ros, Mol. Phys. 1979, 38, 1909-1929.

[37] a) F. Maseras, K. Morokuma, J. Comput. Chem. 1995, 16, 1170-1179; b) F. Maseras, Chem. Commun. 2000, 1821-1827.

[38] a) M. Clark, R. D. III Cramer, N. van Opdenbosch, J. Comput. Chem. 1989, 10, 982-1012; b) U. C. Sing, P. A. Kollman, J. Comput. Chem. 1986, 7, 718-730.

[39] A. K. Rappé, C. J. Casewit, K. S. Colwell, W. A. III Goddard, W. M. Skiff, J. Am. Chem. Soc. 1992, 114, 10024-10035. 